\title{
SLUDGE BATCH 4 (SB4) AFTER A TANK 40 DECANT: CANDIDATE FRITS, MAR ASSESSMENTS, AND GLASSES FOR A VARIABILITY STUDY
}

K.M. Fox

T.B. Edwards

D.K. Peeler

October 2006

Process Science and Engineering Section Savannah River National Laboratory Aiken, SC 29808

Prepared for the U.S. Department of Energy Under Contract Number DEAC09-96SR18500

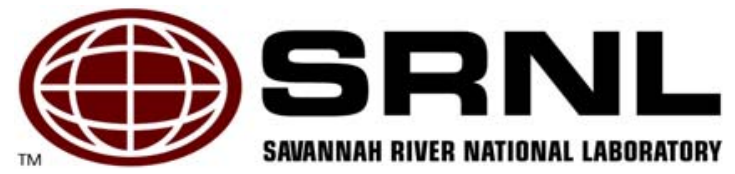




\section{DISCLAIMER}

This report was prepared by Washington Savannah River Company (WSRC) for the United States Department of Energy under Contract No. DE-AC09-96SR18500 and is an account of work performed under that contract. Neither the United States Department of Energy, nor WSRC, nor any of their employees makes any warranty, expressed or implied, or assumes any legal liability or responsibility for the accuracy, completeness, or usefulness, of any information, apparatus, or product or process disclosed herein or represents that its use will not infringe privately owned rights. Reference herein to any specific commercial product, process, or service by trademark, name, manufacturer or otherwise does not necessarily constitute or imply endorsement, recommendation, or favoring of same by WSRC or by the United States Government or any agency thereof. The views and opinions of the authors expressed herein do not necessarily state or reflect those of the United States Government or any agency thereof.

\section{Printed in the United States of America \\ Prepared For \\ U.S. Department of Energy}

The Savannah River National Laboratory is operated for the U.S. Department of Energy by Washington Savannah River Company. 
Keywords: high level waste, glass, SB4, variability, durability

Retention: permanent

\section{SLUDGE BATCH 4 (SB4) AFTER A TANK 40 DECANT: CANDIDATE FRITS, MAR ASSESSMENTS, AND GLASSES FOR A VARIABILITY STUDY}

K.M. Fox

T.B. Edwards

D.K. Peeler

October 2006

Process Science and Engineering Section Savannah River National Laboratory Aiken, SC 29808 


\section{REVIEWS AND APPROVALS}

\section{AUTHORS:}

K.M. Fox, Materials Science and Technology Section

Date

T.B. Edwards, Statistical Consulting Section

Date

D.K. Peeler, Process Science and Engineering Section

Date

TECHNICAL REVIEWER:

M.E. Smith, Process Science and Engineering Section

Date

\section{APPROVERS:}

R.E. Edwards, Manager, Process Science and Engineering Section

Date

C.C. Herman, Manager, Process Engineering Technology Group

Date

J.E. Occhipinti, Manager, DWPF Process Engineering

Date 
WSRC-STI-2006-00305

Revision 0

\section{EXECUTIVE SUMMARY}

In early October 2006, the Liquid Waste Organization (LWO) began to consider decanting Tank 40 at the end of Sludge Batch 3 (SB3) processing and transferring the aqueous phase from the decant to Tank 51. This transfer would be done to decrease Tank 51 yield stress and facilitate the transfer of the contents of Tank 51 to Tank 40. The projected composition of Sludge Batch 4 (SB4) was adjusted by LWO to reflect the impact of the Tank 40 decant leading to new projected compositions for SB4, designated as the 10-0406 and the 10-10-06 compositions. A comparison between these SB4 compositions and those provided in June 2006 indicates that the new compositions are slightly higher in $\mathrm{Al}_{2} \mathrm{O}_{3}, \mathrm{Fe}_{2} \mathrm{O}_{3}$, and $\mathrm{U}_{3} \mathrm{O}_{8}$ and slightly lower in $\mathrm{SiO}_{2}$. The most dramatic change, however, is the new projection's $\mathrm{Na}_{2} \mathrm{O}$ concentration, which is more than $4.5 \mathrm{wt} \%$ lower than the June 2006 projection. ${ }^{\text {a }}$ This is a significant change due to the frit development team's approach of aligning the $\mathrm{Na}_{2} \mathrm{O}$ concentration in a candidate frit to the $\mathrm{Na}_{2} \mathrm{O}$ content of the sludge. This approach enhances the projected operating window and the waste throughput potential for the resulting glass system while eliminating the potential for nepheline crystallization. Nepheline can have a detrimental impact on durability.

Questions surfaced regarding the applicability of Frit 503 to these revised compositions since the Savannah River National Laboratory (SRNL) recommended Frit 503 for use with SB4 based on the June 2006 compositional projection without the Tank 40 decant. Based on the paper study assessments, the change in SB4's expected $\mathrm{Na}_{2} \mathrm{O}$ content had a significant, negative impact on the projected operating window for the Frit 503/SB4 glass system. While Frit 418 had slightly smaller waste loading (WL) intervals for the June 2006 SB4 projections as compared to Frit 503 and the Frit 418 glass systems were nepheline limited, Frit 418 had a slightly larger operating window for the 10-04-06 projection (as compared to Frit 503) and the Frit 418/10-04-06 glass system was no longer nepheline limited. Thus, strictly from the perspective of this paper study, Frit 418 was more attractive than Frit 503 for the new SB4 projected compositions. This comparison, however, does not reflect other aspects of interest for the glass systems such as their respective melt rates or the development of alternative frits to balance the projected operating windows, melt rate, waste throughput, and robustness to compositional variation.

In discussions with Waste Solidification Engineering (WS-E) regarding the results being presented in this report, their decision was to utilize Frit 418 for initial processing of SB4. This decision was not only based on the paper study assessments presented in this report, but also on the fact that Frit 418 is currently being used to process SB3 and, perhaps more importantly, frit optimization efforts for SB4 may be premature given the uncertainties in tank transfer and heel volumes associated with the SB4 flowsheet. More specifically, WS-E indicated their plan to initiate processing with Frit 418 with subsequent authorization for the frit development team to optimize a frit based on the measured composition of SB4 after determination of the actual SB4 blend composition (i.e., both the SB3 and SB4 compositions and masses are known).

Given this decision and recognizing that a SB4/Frit 503 variability study had been initiated as part of the qualification process, questions regarding the need for a supplemental variability study to demonstrate applicability of the process control models for a Frit 418 based system surfaced. This report addresses the need for a supplemental study and defines additional glasses to fill the compositional gaps. A total of 13 glasses (based on the 10-10-06 projection) were selected for the supplemental SB4/Frit 418 variability study. These glasses will be batched and melted following standard SRNL procedures, and a suite of characterization testing will be completed to measure the chemical durability of each glass composition.

\footnotetext{
a The most recent composition changes are a result of using the Sludge Receipt and Adjustment Tank (SRAT) and/or updated Tank 51 compositional information based on the SB4 qualification sample and proposed Tank 40 decant. The June 2006 composition was based on the early analyses of SB4 and the WAPS sample analyses of SB3.
} 


\section{TABLE OF CONTENTS}

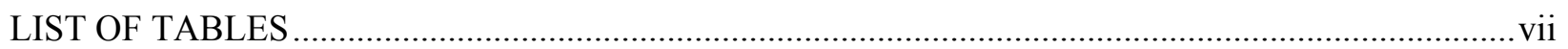

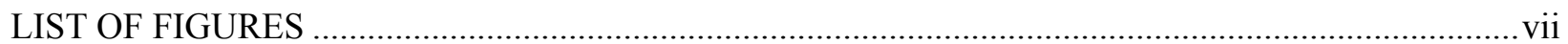

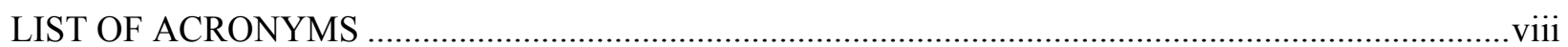

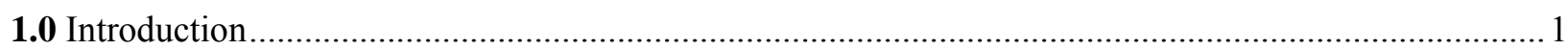

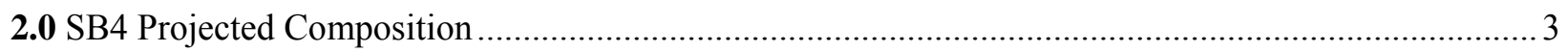

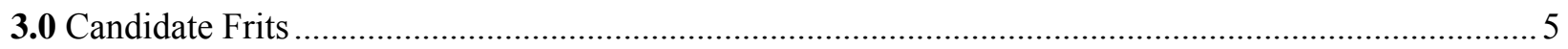

4.0 Nominal Stage Assessment - the Approach and the Results ........................................................ 7

5.0 Variation Stage Assessment - the Approach and the Results ........................................................ 13

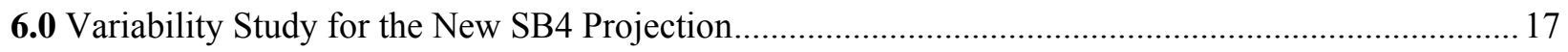

7.0 Selecting Target Compositions of Selected Glasses .......................................................................21

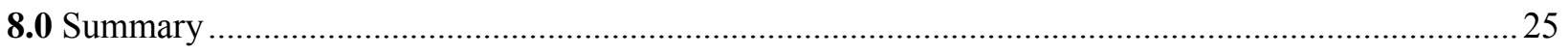

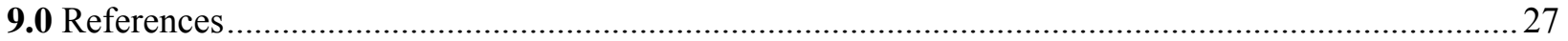




\section{LIST OF TABLES}

Table 2-1. Nominal SB4 Projected Compositions (wt \% calcine basis) ................................................... 3

Table 3-1. Nominal Compositions (in wt \%) of Candidate Frits. .............................................................. 6

Table 4-1. Waste Loadings for the Projected Operating Windows from the Nominal

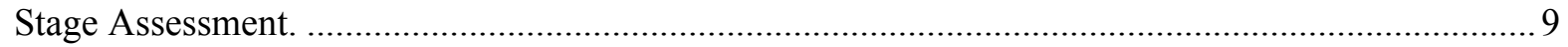

Table 5-1. Nominal 10-10-06 SB4 Composition Projection and Sludge Composition Space with Traditional Variation Applied.

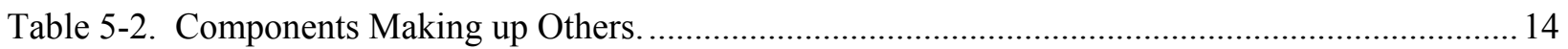

Table 5-3. MAR Results for the Centroid and Percent of EVs that Satisfy the MAR for the 10-10-06 SB4 Projection with Frit 418.

Table 6-1 Projected Glass Space (Mins and Maxs) for the 10-10-06 Projection/Frit Systems (over $25-45 \% \mathrm{WL}$ ). 18

Table 6-2. Historical glasses with sludge compositions similar to the revised SB4 projection.

Table 7-1. D-Optimal Set of 11 EVs for Projected SB4 Composition with Variation. ............................21

Table 7-2. Selected Glasses for the SB4/Frit 418 VS with Property Predictions. ...................................22

Table 7-3. Target Glass Compositions for Frit 418 with the Centroid SB4 Composition (in wt\%).........23

Table 7-4. Target Glass Compositions for Frit 418 with the Inner Layer SB4 EVs (in wt\%).................24

\section{LIST OF FIGURES}

Figure 7-1 Assessment of PCCS MAR Criteria for SB4/Frit 418 Glasses 


\section{LIST OF ACRONYMS}

$\begin{array}{ll}\text { ARP } & \text { Actinide Removal Process } \\ \text { DWPF } & \text { Defense Waste Processing Facility } \\ \text { EVs } & \text { Extreme Vertices } \\ \text { HLW } & \text { High Level Waste } \\ \text { LWO } & \text { Liquid Waste Organization } \\ \text { MAR } & \text { Measurement Acceptability Region } \\ \text { MCU } & \text { Modular Caustic Side Solvent Extraction Unit } \\ \text { PCCS } & \text { Product Composition Control System } \\ \text { SB3 / SB4 } & \text { Sludge Batch 3 Sludge Batch 4 } \\ \text { SME } & \text { Slurry Mix Evaporator } \\ \text { SRNL } & \text { Savannah River National Laboratory } \\ \text { VS } & \text { Variability Study } \\ \text { WL } & \text { Waste Loading (weight percent) } \\ \text { WS-E } & \text { Waste Solidification Engineering }\end{array}$


WSRC-STI-2006-00305

Revision 0

\subsection{Introduction}

The Defense Waste Processing Facility (DWPF) is preparing for vitrification of Sludge Batch 4 (SB4) in early FY2007. To support this process, the Savannah River National Laboratory (SRNL) has provided a recommendation for the frit compositions to be used in vitrifying this sludge batch. ${ }^{1}$ The primary frit recommended for use with SB4 was Frit 503. Frit 418 was identified as a viable frit for the transition from Sludge Batch 3 (SB3) to SB4 (i.e. when the sludge composition is somewhere between that of SB3 and SB4). This frit was recommended primarily to reduce DWPF's inventory of Frit 418 while producing an acceptable glass product. These recommendations were based on composition projections for SB4 that were provided to SRNL in June 2006 , a assessments of operating windows in terms of waste loading (WL), ${ }^{2-7}$ melt rate data, ${ }^{8}$ the potential for nepheline formation (a crystalline phase that can be detrimental to product performance) and the chemical durability of test glasses. ${ }^{9-16}$ To support the SB4 qualification process, a glass variability study ${ }^{17,18}$ was initiated to confirm the applicability of the durability models, ${ }^{19}$ which are used as part of the DWPF's process control strategy, to the SB4/Frit 503 glass system with some coverage of the SB4/Frit 418 glass system. This variability study, which was intended to support the projected composition of SB4 provided in June 2006, will be referred to as the SB4/Frit 503 Variability Study (VS) throughput this report.

As the SB4/Frit 503 VS results were being documented and reviewed in early October 2006, the Liquid Waste Organization (LWO) was exploring the possibility of decanting Tank 40 at the end of SB3 processing to transfer some fraction of the aqueous phase (supernate) to Tank 51 to facilitate the transfer of the contents of that tank back into Tank 40. More specifically, the supernate of Tank 40 would be used to alter rheological properties of the Tank 51 sludge to aid transfer back to Tank 40. The resulting sludge in Tank 40 would then become SB4, and the projected composition for the new version of this sludge was adjusted by LWO to reflect the impact of the Tank 40 decant. This decant would serve an additional benefit to the Tank Farm since the insoluble solids in Tank 40 would be maximized and recycle would be minimized.

Two projected compositions, designated as the 10-04-06 and the 10-10-06 projections, were issued to $\mathrm{SRNL}^{\mathrm{b}}$ by LWO so that the frit development team could:

- add the anticipated sulfate concentration and renormalize the SB4 composition as calcine sludge oxides;

- compare the 10-04-06 and 10-10-06 calcine projections to the projections utilized by SRNL in June 2006 to support the Frit 503 recommendation and the SB4/Frit 503 VS;

- identify candidate frits for use with the new projections for SB4 (including Frit 503 and Frit 418);

- develop the projected operating windows for the candidate frit/sludge glass systems;

- identify a frit or frits for use with the new projections; and

\footnotetext{
a Personal communication with H. B. Shah, via email, on June 22, 2006 (see WSRC-NB-2006-00017, pp. 51 - 53 for details) for compositions assuming a $\sim 113$ " heel in Tank 40 and a blend date after meeting canister production goal (mid-November 2006).

${ }^{\mathrm{b}}$ Site emails communicated from H. B. Shah on October 4 and October 10 of 2006 (see WSRC-NB-2006-00017, pp. 86 - 94 for details). The 10-04-06 SB4 composition was initially used as the technical basis for the nominal stage assessments discussed in this report to identify candidate frits. Based on initial feedback to the LWO and DWPF using the 10-04-06 compositional projections, a decision was made to utilize (at least initially) Frit 418 for processing SB4. This decision was made, in part, due to the uncertainty of the composition for SB4, which may not be well understood until the processing of this sludge actually begins. This decision was made prior to the receipt of the 10-10-06 composition which was ultimately used to support the development of the SB4/Frit 418 supplemental variability study test matrix.
} 
- identify additional glasses that are to be fabricated and tested to complement any existing glasses to serve as a technical basis for a variability study for the anticipated glass system. It is the purpose of this report to address each of these issues. 


\subsection{SB4 Projected Composition}

The new projected sludge compositions that were considered in this study are provided in the first two columns of Table 2-1. Elemental concentrations for these options were provided to the frit development team by LWO, ${ }^{20}$ and these were converted to oxide concentrations by multiplying the values for each element by the gravimetric factor for the corresponding oxide. The compositions submitted to the frit development team did not include estimates of the $\mathrm{SO}_{4}{ }^{2-}$ concentrations. However, LWO personnel did provide information, as part of the washing scenarios and preparation plans, which was used to derive an estimate for the $\mathrm{SO}_{4}{ }^{2-}$ concentration. The concentration was added to the oxide list and the resulting oxide concentrations were then normalized to $100 \%$. It should be noted that the projected sludge compositions presented in Table 2-1 are sludge-only flowsheets and do not account for any potential secondary streams from the Actinide Removal Process (ARP) or the Modular Caustic Side Solvent Extraction Unit (MCU). These auxiliary streams are not considered in this report.

Table 2-1. Nominal SB4 Projected Compositions (wt\% calcine basis).

\begin{tabular}{|c|c|c|c|c|}
\hline Oxide & $\begin{array}{l}\text { 10-04-06 } \\
\text { SB4 } \\
\text { Projection }\end{array}$ & $\begin{array}{l}\text { 10-10-06 } \\
\text { SB4 } \\
\text { Projection }\end{array}$ & $\begin{array}{c}\text { June } 2006 \\
\text { SB4 Blend-1 at } \\
12.2 \text { wt } \% \text { solids, }^{+} \\
0.92 \mathrm{M} \mathrm{Na}^{+}\end{array}$ & $\begin{array}{c}\text { June } 2006 \\
\text { SB4 Blend-1 at } \\
12.6 \text { wt\% solids, } \\
0.912 \mathrm{M} \mathrm{Na}^{+}\end{array}$ \\
\hline & Blend 1 Processing & Blend 1 Processing & Processing & Processing \\
\hline $\mathrm{Al}_{2} \mathrm{O}_{3}$ & 25.65 & 25.490 & 23.750 & 23.965 \\
\hline $\mathrm{BaO}$ & 0.07 & 0.070 & 0.124 & 0.125 \\
\hline $\mathrm{CaO}$ & 2.79 & 2.765 & 2.350 & 2.371 \\
\hline $\mathrm{Ce}_{2} \mathrm{O}_{3}$ & 0.22 & 0.214 & 0.150 & 0.151 \\
\hline $\mathrm{Cr}_{2} \mathrm{O}_{3}$ & 0.20 & 0.198 & 0.208 & 0.210 \\
\hline $\mathrm{CuO}$ & 0.05 & 0.051 & 0.060 & 0.060 \\
\hline $\mathrm{Fe}_{2} \mathrm{O}_{3}$ & 29.20 & 28.989 & 26.165 & 26.401 \\
\hline $\mathrm{K}_{2} \mathrm{O}$ & 0.07 & 0.068 & 0.329 & 0.332 \\
\hline $\mathrm{La}_{2} \mathrm{O}_{3}$ & 0.03 & 0.031 & 0.106 & 0.107 \\
\hline $\mathrm{MgO}$ & 2.79 & 2.774 & 2.480 & 2.502 \\
\hline $\mathrm{MnO}$ & 5.83 & 5.783 & 5.394 & 5.443 \\
\hline $\mathrm{Na}_{2} \mathrm{O}$ & 18.22 & 18.708 & 23.888 & 23.261 \\
\hline $\mathrm{NiO}$ & 1.67 & 1.660 & 1.545 & 1.559 \\
\hline $\mathrm{PbO}$ & 0.39 & 0.383 & 0.091 & 0.092 \\
\hline $\mathrm{SO}_{4}^{2-}$ & 0.79 & 0.866 & 1.417 & 1.368 \\
\hline $\mathrm{SiO}_{2}$ & 2.73 & 2.711 & 3.963 & 3.998 \\
\hline $\mathrm{ThO}_{2}$ & 0.03 & 0.031 & 0.063 & 0.063 \\
\hline $\mathrm{TiO}_{2}$ & 0.04 & 0.035 & 0.026 & 0.026 \\
\hline $\mathrm{U}_{3} \mathrm{O}_{8}$ & 9.10 & 9.031 & 7.563 & 7.632 \\
\hline $\mathrm{ZnO}$ & 0.05 & 0.000 & 0.098 & 0.099 \\
\hline $\mathrm{ZrO}_{2}$ & 0.09 & 0.050 & 0.233 & 0.235 \\
\hline SUM & 100.00 & 100.00 & 100.00 & 100.00 \\
\hline
\end{tabular}

The last two columns of Table 2-1 reflect the June 2006 SB4 projected compositions that served as the basis for SRNL's Frit 503 recommendation ${ }^{1}$ and for the SB4/Frit 503 VS. $^{17,}{ }^{18}$ A comparison between the new projected sludge compositions and those studied previously indicates that the new compositions are slightly higher in $\mathrm{Al}_{2} \mathrm{O}_{3}, \mathrm{Fe}_{2} \mathrm{O}_{3}$, and $\mathrm{U}_{3} \mathrm{O}_{8}$ and slightly lower in $\mathrm{SiO}_{2}$. The most dramatic changes are in the $\mathrm{Na}_{2} \mathrm{O}$ and $\mathrm{SO}_{4}{ }^{2-}$ concentrations. The $\mathrm{Na}_{2} \mathrm{O}$ is more than $4.5 \mathrm{wt} \%$ 
lower in the October projections as compared to those used in June assessments. ${ }^{\text {a }}$ This is a significant change due to the frit development team's approach of aligning the $\mathrm{Na}_{2} \mathrm{O}$ concentration in a candidate frit to the $\mathrm{Na}_{2} \mathrm{O}$ content of the sludge. This approach is taken to enhance the projected operating window and the waste throughput potential for the resulting glass system while minimizing the possible negative impacts of nepheline formation on durability. This degree of change in SB4's expected $\mathrm{Na}_{2} \mathrm{O}$ content may have a detrimental impact on the projected operating window for the SB4/Frit 503 glass system. This issue is addressed in the following sections.

With respect to the $\mathrm{SO}_{4}{ }^{2-}$ concentrations, the revised values are almost a factor of 2 lower than previous projections. These lower values translate into reduced risks of exceeding the $\mathrm{SO}_{4}{ }^{2-}$ solubility limit for the specific frit - SB4 system of interest. More specifically, assuming a $0.6 \mathrm{wt} \% \mathrm{SO}_{4}{ }^{2-}$ (in glass) Product Composition Control System (PCCS) limit for the SB4 system, WLs greater than $\sim 70 \%$ would be required before either the 10-04-06 or the 10-10-06 systems would become $\mathrm{SO}_{4}{ }^{2-}$ limited. Other process related parameters such as melt rate, liquidus temperature, or nepheline formation will be more restrictive with respect to accessing higher WLs.

a The most recent composition changes are a result of using the Sludge Receipt and Adjustment Tank (SRAT) and/or updated Tank 51 compositional information based on the SB4 qualification sample and proposed Tank 40 decant. The June 2006 composition was based on the early analyses of SB4 and the WAPS sample analyses of SB3. 


\subsection{Candidate Frits}

Table 3-1 provides the candidate frits and their nominal compositions (on a wt $\%$ basis) that were considered in the assessment of the new SB4 compositions. A closer review of Frits 422 through X1-1 (shaded in Table 3-1) indicates fixed concentrations of $\mathrm{B}_{2} \mathrm{O}_{3}$ and $\mathrm{Li}_{2} \mathrm{O}$ at $8 \mathrm{wt} \%$ with only the $\mathrm{Na}_{2} \mathrm{O}$ and $\mathrm{SiO}_{2}$ concentrations varying. In general, these frit compositions reflect an increase in $\mathrm{Na}_{2} \mathrm{O}$ by $1 \%$ with a corresponding decrease in $\mathrm{SiO}_{2}$, proceeding from Frit 422 to Frit X1-1. This system has been referred to as a "sliding $\mathrm{Na}_{2} \mathrm{O}$ scale," a concept that was developed to accommodate potential sludge $\mathrm{Na}_{2} \mathrm{O}$ concentration differences as a result of various washing strategies considered for SB3. ${ }^{21}$

Frits 202 and 200 are historical frits that were developed to support the coupled and sludge-only flowsheets, respectively. They are included in this assessment to provide insight into their potential use with the latest SB4 compositional projection. The "P-series", T1-1, "418-m" series, and the " $200-\mathrm{m}$ " series of frits have been developed to minimize the potential for nepheline formation given its impact on durability. ${ }^{12-14,16}$ In general, these frits have lower $\mathrm{Na}_{2} \mathrm{O}$ concentrations than the "sliding $\mathrm{Na}_{2} \mathrm{O}$ scale" series, with the differences being accounted for by increases in $\mathrm{Li}_{2} \mathrm{O}, \mathrm{B}_{2} \mathrm{O}_{3}$, and/or $\mathrm{Fe}_{2} \mathrm{O}_{3}$ (individually or in combination). The intent in introducing this series of frits was to find combinations of $\mathrm{Na}_{2} \mathrm{O}$ and $\mathrm{SiO}_{2}$ concentrations that suppressed the potential for nepheline formation to higher WLs with the adjustments in $\mathrm{Li}_{2} \mathrm{O}, \mathrm{B}_{2} \mathrm{O}_{3}$, and/or $\mathrm{Fe}_{2} \mathrm{O}_{3}$, with the hope of maintaining (or regaining) melt rate, which would presumably be lower for glass systems with lower $\mathrm{Na}_{2} \mathrm{O}$ concentrations. In fact, Frit 503 (previously referred to as $418-\mathrm{m} 10$ ) is one of the "418-m" series frits that was ultimately recommended for SB4 processing based on the June compositional projections. 
Table 3-1. Nominal Compositions (in wt\%) of Candidate Frits.

\begin{tabular}{|c|c|c|c|c|c|c|}
\hline \multirow{2}{*}{ Frit } & \multicolumn{6}{|c|}{ "Oxide Composition } \\
\hline & $\mathrm{B}_{2} \mathrm{O}_{3}$ & $\mathrm{Fe}_{2} \mathrm{O}_{3}$ & $\mathbf{L i}_{2} \mathbf{O}$ & MgO & $\mathrm{Na}_{2} \mathrm{O}$ & $\mathrm{SiO}_{2}$ \\
\hline 202 & 8 & 0 & 7 & 2 & 6 & 77 \\
\hline 422 & 8 & 0 & 8 & 0 & 3 & 81 \\
\hline $\mathrm{d} 1-1$ & 8 & 0 & 8 & 0 & 4 & 80 \\
\hline 473 & 8 & 0 & 8 & 0 & 5 & 79 \\
\hline 432 & 8 & 0 & 8 & 0 & 6 & 78 \\
\hline 460 & 8 & 0 & 8 & 0 & 7 & 77 \\
\hline 418 & 8 & 0 & 8 & 0 & 8 & 76 \\
\hline 426 & 8 & 0 & 8 & 0 & 9 & 75 \\
\hline 425 & 8 & 0 & 8 & 0 & 10 & 74 \\
\hline 417 & 8 & 0 & 8 & 0 & 11 & 73 \\
\hline 320 & 8 & 0 & 8 & 0 & 12 & 72 \\
\hline 431 & 8 & 0 & 8 & 0 & 13 & 71 \\
\hline Y1-1 & 8 & 0 & 8 & 0 & 14 & 70 \\
\hline $\mathrm{X} 1-1$ & 8 & 0 & 8 & 0 & 15 & 69 \\
\hline P3-4 & 8 & 0 & 10 & 0 & 7 & 75 \\
\hline P3-1/502 & 8 & 0 & 11 & 0 & 5 & 76 \\
\hline P3-2 & 8 & 1 & 10 & 0 & 6 & 75 \\
\hline P3-3 & 8 & 1 & 10 & 0 & 7 & 74 \\
\hline $\mathrm{t} 1-1$ & 8 & 2 & 8 & 0 & 5 & 77 \\
\hline $418-\mathrm{m} 2$ & 8 & 3 & 8 & 0 & 5 & 76 \\
\hline 418-m6 & 8 & 3 & 8 & 0 & 5 & 76 \\
\hline P2-3 & 8 & 3 & 10 & 0 & 6 & 73 \\
\hline P1-1 & 8 & 4 & 8 & 0 & 5 & 75 \\
\hline $\mathrm{P} 2-1$ & 8 & 4 & 10 & 0 & 5 & 73 \\
\hline P2-5 & 8 & 5 & 10 & 0 & 7 & 70 \\
\hline P2-2 & 8 & 5 & 11 & 0 & 5 & 71 \\
\hline P2-4 & 8 & 5 & 11 & 0 & 6 & 70 \\
\hline $418-\mathrm{ml} / 501$ & 9 & 0 & 10 & 0 & 5 & 76 \\
\hline $418-\mathrm{m} 3$ & 9 & 1 & 9 & 0 & 5 & 76 \\
\hline $418-\mathrm{m} 4$ & 9 & 2 & 8 & 0 & 5 & 76 \\
\hline 200-m1 & 10 & 0 & 9 & 0 & 5 & 76 \\
\hline $418-\mathrm{m} 7$ & 10 & 1 & 9 & 0 & 5 & 75 \\
\hline 418-m5 & 11 & 0 & 8 & 0 & 5 & 76 \\
\hline 418-m8 & 11 & 1 & 9 & 0 & 4 & 75 \\
\hline 200 & 12 & 0 & 5 & 2 & 11 & 70 \\
\hline
\end{tabular}

\begin{tabular}{|c|c|c|c|c|c|c|}
\hline \multirow{2}{*}{ Frit } & \multicolumn{6}{|c|}{ Oxide Composition } \\
\hline & $\mathrm{B}_{2} \mathrm{O}_{3}$ & $\mathrm{Fe}_{2} \mathrm{O}_{3}$ & $\mathbf{L i}_{2} \mathbf{O}$ & MgO & $\mathrm{Na}_{2} \mathrm{O}$ & $\mathrm{SiO}_{2}$ \\
\hline $418-\mathrm{m} 11$ & 12 & 0 & 8 & 0 & 4 & 76 \\
\hline $418-\mathrm{m} 16$ & 12 & 0 & 8 & 0 & 5 & 75 \\
\hline $200-\mathrm{m} 2$ & 12 & 0 & 9 & 0 & 5 & 74 \\
\hline 418-m9 & 12 & 1 & 9 & 0 & 4 & 74 \\
\hline $418-\mathrm{m} 15$ & 13 & 0 & 8 & 0 & 5 & 74 \\
\hline $503-\mathrm{m} 10$ & 14 & 0 & 5 & 0 & 10 & 71 \\
\hline 503-m9 & 14 & 0 & 6 & 0 & 8 & 72 \\
\hline $503-\mathrm{m} 8$ & 14 & 0 & 7 & 0 & 6 & 73 \\
\hline $418-\mathrm{m} 10 / 503$ & 14 & 0 & 8 & 0 & 4 & 74 \\
\hline $503-\mathrm{ml}$ & 14 & 0 & 8 & 0 & 5 & 73 \\
\hline $418-\mathrm{m} 20 / 505$ & 14 & 0 & 8 & 0 & 6 & 72 \\
\hline $503-\mathrm{m} 2$ & 14 & 0 & 8 & 0 & 7 & 71 \\
\hline $503-\mathrm{m} 3$ & 14 & 0 & 8 & 0 & 8 & 70 \\
\hline $503-\mathrm{m} 4$ & 14 & 0 & 8 & 0 & 9 & 69 \\
\hline 503-m5 & 14 & 0 & 8 & 0 & 10 & 68 \\
\hline 418-m24 & 14 & 4 & 8 & 0 & 4 & 70 \\
\hline $418-\mathrm{m} 23 / 506$ & 14 & 4 & 8 & 0 & 6 & 68 \\
\hline $418-\mathrm{m} 28 / 507$ & 14 & 4 & 10 & 0 & 4 & 68 \\
\hline $418-\mathrm{m} 31$ & 14 & 4 & 9 & 0 & 5 & 68 \\
\hline $418-\mathrm{m} 32$ & 14 & 5 & 9 & 0 & 4 & 68 \\
\hline $418-\mathrm{m} 25$ & 14 & 6 & 8 & 0 & 4 & 68 \\
\hline $418-\mathrm{m} 29$ & 14 & 6 & 10 & 0 & 4 & 66 \\
\hline $418-\mathrm{m} 26$ & 14 & 8 & 8 & 0 & 4 & 66 \\
\hline 418-m30 & 14 & 8 & 10 & 0 & 4 & 64 \\
\hline 418-m12 & 16 & 0 & 8 & 0 & 4 & 72 \\
\hline 418-m17 & 16 & 0 & 8 & 0 & 5 & 71 \\
\hline 418-m21 & 16 & 0 & 8 & 0 & 6 & 70 \\
\hline 503-m6 & 16 & 0 & 8 & 0 & 8 & 68 \\
\hline 503-m7 & 16 & 0 & 8 & 0 & 10 & 66 \\
\hline $418-\mathrm{m} 13$ & 18 & 0 & 8 & 0 & 4 & 70 \\
\hline $418-\mathrm{m} 18$ & 18 & 0 & 8 & 0 & 5 & 69 \\
\hline $418-\mathrm{m} 22$ & 18 & 0 & 8 & 0 & 6 & 68 \\
\hline $418-\mathrm{m} 14 / 504$ & 20 & 0 & 8 & 0 & 4 & 68 \\
\hline 418-m19 & 20 & 0 & 8 & 0 & 5 & 67 \\
\hline
\end{tabular}




\subsection{Nominal Stage Assessment - the Approach and the Results}

What is the impact of the new SB4 projected composition on the viability of processing this sludge with Frit 503 or with Frit 418? Are there other candidate frits that provide attractive operating windows with the new projected composition for SB4? To answer these questions, a Nominal Stage assessment was conducted using the 10-04-06 SB4 projection. This assessment is a screening tool that is typically applied to a large set of candidate frits to identify those worthy of additional study - specifically, a Variation Stage assessment. ${ }^{\mathrm{a}}$

There are 69 frits in Table 3-1, and for the Nominal Stage assessment, all of these frits were considered with the 10-04-06 SB4 projection (i.e., the first column of Table 2-1) and with the two previously studied SB4 projections (i.e., the last two columns of Table 2-1). This allows for comparisons to be readily made between the predicted operating windows for the new and previous SB4 projections. Of particular interest will be the comparisons for Frit 503 and Frit 418 for the different SB4 compositional views, as well as the identification of other frit alternatives that are projected to lead to attractive operating windows with the new SB4 composition.

As in the past, the assessment conducted as part of this effort was strictly a paper study that was driven by predictions from glass property/glass composition models. However, the assessments do provide meaningful insight into the viability of sludge/frit glass systems since the models used in the assessments are the same as the models which will be in DWPF's PCCS during the processing of SB4. The major property models included those for liquidus temperature $\left(\mathrm{T}_{\mathrm{L}}\right)$, viscosity $(\eta)$, and durability (as defined by the Product Consistency Test) response in terms of the preliminary glass dissolution estimator $\left(\Delta \mathrm{G}_{\mathrm{P}}\right.$ or Del $\left.\mathrm{Gp}\right) .{ }^{19}$ It should be noted that the proposed durability limits by Edwards et al. ${ }^{22}$ and the new viscosity model developed by Jantzen ${ }^{23}$ were used in this assessment. ${ }^{\mathrm{b}}$ Jantzen et al., ${ }^{19}$ Brown et al., ${ }^{24}$ and Brown, Postles, and Edwards ${ }^{25}$ provide more detailed discussions on the development of the PCCS models and the constraints imposed on the DWPF operation including a relatively new constraint to limit the potential for the formation of a nepheline primary crystalline phase. ${ }^{10}$ This constraint was based on a nepheline discriminator function ${ }^{\mathrm{c}}$ described by Li et al. ${ }^{26}$

For the Nominal Stage assessment, glass compositions were generated to represent combinations of the 10-04-06 SB4 projection with each candidate frit at waste loadings of interest. The acceptability of the model predictions for a particular glass composition for this stage as well as the Variation Stage (to be described later) was judged by employing the same criteria that are used by PCCS in its Slurry Mix Evaporator (SME) acceptability decisions. Acceptable predicted properties for the assessment are based on satisfying their respective Measurement Acceptability

\footnotetext{
a Based on initial feedback to the LWO and DWPF using the 10-04-06 compositional projections, a decision was made to utilize (at least initially) Frit 418 for processing SB4. This decision was made, in part, due to the uncertainty of the composition for SB4, which may not be well understood until the processing of this sludge actually begins. This decision was made prior to the receipt of the 10-10-06 composition. The latter composition (10-10-06) was ultimately used to support the development of the SB4/Frit 418 supplemental variability study test matrix as will be discussed.

$\mathrm{b}$ The new durability limits and the new viscosity model were used since both models are currently being implemented in DWPF to support SB4 processing. The durability limits remove excess conservatism in the current model without compromising product quality and provide access to higher alkali compositional regions that may improve melt rate and/or waste loading. The modifications to implement the new viscosity model in PCCS are described by Edwards and Peeler in the memorandum SRNL-SCS-2005-00054.

c Sodium alumino-borosilicate glasses are prone to nepheline crystallization if their compositions projected on the $\mathrm{Na}_{2} \mathrm{O}-\mathrm{Al}_{2} \mathrm{O}_{3}-\mathrm{SiO}_{2}$ ternary fall within the nepheline primary phase field. In particular, durable glasses with $\mathrm{SiO}_{2} /\left(\mathrm{SiO}_{2}+\mathrm{Na}_{2} \mathrm{O}+\mathrm{Al}_{2} \mathrm{O}_{3}\right)>0.62$, where the oxides are expressed as mass fractions in the glass, do not precipitate nepheline as their primary phase. ${ }^{26}$
} 
Region (MAR) limits. Brown, Postles, and Edwards ${ }^{25}$ provide a detailed discussion of how the MAR limits are utilized for SME acceptability decisions in PCCS. Thus, the value of the frit development effort in its assessment of a glass composition is that it mirrors the results that would be generated by the PCCS MAR criteria for the same glass at DWPF. The results of this assessment are provided in Table 4-1.

To aid the interpretation of results presented in Table 4-1, a description of the terminology used and a brief discussion of a specific example are warranted. The first column (labeled "Frit") contains the 69 frits as shown in Table 3-1. The remaining three major column headers (10-04-06 SB4 Projection, SB4 Blend-1 at $12.2 \mathrm{wt} \%$ solids, $0.92 \mathrm{M} \mathrm{Na}^{+}$, and SB4 Blend-1 at $12.6 \mathrm{wt} \%$ solids, $0.912 \mathrm{M} \mathrm{Na}^{+}$) represent the three sludge compositional views. For each frit - sludge combination, there are three sub-columns of information. The middle column represents the WL interval over which glasses are acceptable based on predicted properties as compared to MAR acceptability criteria. The entries to the left and right of this center column indicate the property (or properties) that limit access to lower and higher WLs, respectively. A blank cell indicates that there were no property restrictions below or above 25 and $60 \% \mathrm{WL}$, respectively. Nomenclature for specific properties shown in Table 4-1 include: $\mathrm{T}_{\mathrm{L}}$ (liquidus temperature), hFrit (high Frit), Neph (nepheline), lvisc (low viscosity), hvisc (high viscosity), and Del Gp (durability).

Consider the 10-04-06 SB4/Frit 200 system as an example. The projected operating window is $25-38 \% \mathrm{WL}$ with predictions of $\mathrm{T}_{\mathrm{L}}$ limiting access to higher WLs. There are no restrictions on the lower end of the WL interval of interest (i.e., a blank entry). 
Table 4-1. Waste Loadings for the Projected Operating Windows from the Nominal Stage Assessment.

\begin{tabular}{|c|c|c|c|c|c|c|c|c|c|}
\hline \multirow{2}{*}{$\begin{array}{l}\text { Frit } \\
200 \\
\end{array}$} & \multicolumn{3}{|c|}{ 10-4-06 SB4 Projection } & \multicolumn{3}{|c|}{$\begin{array}{l}\text { SB4 Blend-1 at } 12.2 \text { wt\% solids, } \\
\qquad 0.92 \mathrm{M} \mathrm{Na}^{+}\end{array}$} & \multicolumn{3}{|c|}{$\begin{array}{l}\text { SB4 Blend-1 at } 12.6 \mathrm{wt}^{\circ} \% \text { solids, } \\
0.912 \mathrm{M} \mathrm{Na}^{+}\end{array}$} \\
\hline & & $25-38$ & $\mathrm{TL}$ & & $25-39$ & Neph & & $25-40$ & Neph \\
\hline 200-m1 & & $25-39$ & $\mathrm{TL}$ & hFrit & $26-46$ & Neph & hFrit & $26-46$ & Neph \\
\hline $200-\mathrm{m} 2$ & & $25-39$ & $\mathrm{TL}$ & & $26-45$ & Neph & hFrit & $26-46$ & Neph \\
\hline 202 & & - & & hvisc & $31-44$ & $\mathrm{TL}$ & hvisc & $31-43$ & $\mathrm{TL}$ \\
\hline 320 & & $25-41$ & Neph & hFrit & $26-38$ & lvisc & hvisc & $26-39$ & lvisc \\
\hline 417 & & $25-43$ & Neph & hFrit & $26-41$ & $\begin{array}{l}\text { lvisc } \\
\text { Neph }\end{array}$ & hFrit & $26-41$ & Neph \\
\hline 418 & & $25-42$ & $\mathrm{TL}$ & hFrit & $26-44$ & Neph & hFrit & $26-44$ & Neph \\
\hline 418-m1/501 & & $25-40$ & $\mathrm{TL}$ & hFrit & $26-46$ & Neph & hFrit & $26-46$ & Neph \\
\hline 503 & & $25-37$ & TL & hFrit & $26-46$ & TL Neph & hFrit & $26-45$ & TL \\
\hline 418-m11 & hvisc & $31-37$ & $\mathrm{TL}$ & hFrit & $26-46$ & $\mathrm{TL}$ & hFrit & $26-45$ & $\mathrm{TL}$ \\
\hline 418-m12 & & $25-36$ & $\mathrm{TL}$ & hFrit & $26-45$ & Neph & hFrit & $26-45$ & TL Neph \\
\hline 418-m13 & & $25-36$ & $\mathrm{TL}$ & hFrit & $26-42$ & lvisc & hFrit & $26-43$ & lvisc \\
\hline 418-m14/504 & & $25-36$ & $\mathrm{TL}$ & hFrit & $26-38$ & lvisc & hFrit & 26-39 & lvisc \\
\hline 418-m15 & & $25-38$ & $\mathrm{TL}$ & hFrit & $26-45$ & Neph & hFrit & $26-46$ & TL Neph \\
\hline 418-m16 & & $25-38$ & $\mathrm{TL}$ & hFrit & $26-46$ & Neph & hFrit & $26-46$ & TL Neph \\
\hline 418-m17 & & $25-38$ & $\mathrm{TL}$ & hFrit & $26-43$ & lvisc & hFrit & $26-44$ & $\begin{array}{l}\text { lvisc } \\
\text { Neph }\end{array}$ \\
\hline 418-m18 & & $25-37$ & TL & hFrit & $26-39$ & lvisc & hFrit & $26-40$ & lvisc \\
\hline 418-m19 & & $25-37$ & $\mathrm{TL}$ & hFrit & $26-35$ & $\begin{array}{l}\text { lvisc } \\
\text { Neph } \\
\end{array}$ & hFrit & $26-36$ & lvisc \\
\hline 418-m2 & hvisc & $29-35$ & TL & & $25-44$ & TL & & $25-43$ & $\mathrm{TL}$ \\
\hline 418-m20/505 & & $25-39$ & $\mathrm{TL}$ & hFrit & $26-44$ & $\begin{array}{l}\text { lvisc } \\
\text { Neph }\end{array}$ & hFrit & $26-44$ & Neph \\
\hline 418-m21 & & $25-39$ & TL & hFrit & $26-40$ & lvisc & hFrit & $26-41$ & lvisc \\
\hline 418-m22 & & $25-38$ & $\mathrm{TL}$ & hFrit & $26-36$ & lvisc & hFrit & $26-37$ & lvisc \\
\hline $418-\mathrm{m} 23 / 506$ & & $25-34$ & $\mathrm{TL}$ & & $25-37$ & lvisc & & $25-37$ & lvisc \\
\hline 418-m24 & & $25-31$ & $\mathrm{TL}$ & & $25-41$ & $\mathrm{TL}$ & & $25-39$ & $\mathrm{TL}$ \\
\hline $418-\mathrm{m} 25$ & & $25-29$ & $\mathrm{TL}$ & & $25-37$ & $\mathrm{TL}$ & & $25-36$ & $\mathrm{TL}$ \\
\hline $418-\mathrm{m} 26$ & & $25-26$ & $\mathrm{TL}$ & & $25-34$ & $\mathrm{TL}$ & & $25-33$ & $\mathrm{TL}$ \\
\hline $418-\mathrm{m} 28 / 507$ & & $25-34$ & $\mathrm{TL}$ & & $25-31$ & lvisc & & $25-32$ & lvisc \\
\hline 418-m29 & & $25-32$ & $\mathrm{TL}$ & & $25-26$ & lvisc & & $25-27$ & lvisc \\
\hline 418-m3 & & $25-38$ & $\mathrm{TL}$ & & $25-46$ & Neph & & $25-46$ & Neph \\
\hline 418-m30 & & $25-25$ & lvisc & & - & TL lvisc & & - & TL lvisc \\
\hline 418-m31 & & $25-34$ & $\mathrm{TL}$ & & $25-34$ & lvisc & & $25-35$ & lvisc \\
\hline 418-m32 & & $25-32$ & $\mathrm{TL}$ & & $25-36$ & lvisc & & $25-36$ & lvisc \\
\hline 418-m4 & hvisc & 29-36 & $\mathrm{TL}$ & & $25-46$ & TL Neph & & $25-44$ & $\mathrm{TL}$ \\
\hline 418-m5 & hvisc & 29-38 & $\mathrm{TL}$ & hFrit & $26-46$ & Neph & hFrit & $26-46$ & TL Neph \\
\hline 418-m6 & hvisc & 29-35 & $\mathrm{TL}$ & & $25-44$ & TL & & $25-43$ & $\mathrm{TL}$ \\
\hline 418-m7 & & $25-38$ & $\mathrm{TL}$ & & $25-46$ & Neph & & $25-46$ & Neph \\
\hline 418-m8 & & $25-37$ & TL & & $25-46$ & TL Neph & & $25-45$ & $\mathrm{TL}$ \\
\hline 418-m9 & & $25-37$ & $\mathrm{TL}$ & & $25-46$ & TL Neph & & $25-45$ & $\mathrm{TL}$ \\
\hline 422 & & - & & hvisc & $37-46$ & hvisc & hvisc & $38-44$ & hvisc \\
\hline
\end{tabular}


WSRC-STI-2006-00305

Revision 0

Table 4-1. Waste Loadings for the Projected Operating Windows from the Nominal Stage Assessment

(continued)

\begin{tabular}{|c|c|c|c|c|c|c|c|c|c|}
\hline \multirow{2}{*}{$\begin{array}{l}\text { Frit } \\
425 \\
\end{array}$} & \multicolumn{3}{|c|}{ 10-04-06 SB4 Projection } & \multicolumn{3}{|c|}{$\begin{array}{l}\text { SB4 Blend-1 at } 12.2 \mathrm{wt}^{+} \% \text { solids, } \\
\qquad 0.92 \mathrm{M} \mathrm{Na}^{+}\end{array}$} & \multicolumn{3}{|c|}{$\begin{array}{l}\text { SB4 Blend-1 at } 12.6 \mathrm{wt} \% \text { solids, } \\
0.912 \mathrm{M} \mathrm{Na}^{+}\end{array}$} \\
\hline & & $25-44$ & TL Neph & $\mathrm{hFrit}$ & $26-42$ & Neph & hFrit & $26-42$ & Neph \\
\hline 426 & & $25-43$ & $\mathrm{TL}$ & hFrit & $26-43$ & Neph & hFrit & $26-43$ & Neph \\
\hline 431 & & $25-40$ & Neph & Del Gp & $34-34$ & Del Gp & $\mathrm{hFrit}$ & $26-35$ & lvisc \\
\hline 432 & hvisc & $33-40$ & $\mathrm{TL}$ & hvisc/hFrit & $26-46$ & Neph & hvisc/hFrit & $26-47$ & Neph \\
\hline 460 & hvisc & $27-41$ & $\mathrm{TL}$ & hFrit & $26-45$ & Neph & hFrit & $26-46$ & Neph \\
\hline 473 & hvisc & $38-38$ & TL & hvisc & $30-47$ & hvisc & hvisc & $31-47$ & hvisc \\
\hline 503-m1 & & $25-38$ & $\mathrm{TL}$ & hFrit & $26-45$ & Neph & hFrit & $26-45$ & Neph \\
\hline $503-\mathrm{m} 10$ & & $25-40$ & $\mathrm{TL}$ & hFrit & $26-41$ & Neph & hFrit & $26-41$ & Neph \\
\hline $503-\mathrm{m} 2$ & & $25-40$ & $\mathrm{TL}$ & hFrit & $26-41$ & lvisc & $\mathrm{hFrit}$ & $26-42$ & $\begin{array}{l}\text { lvisc } \\
\text { Neph }\end{array}$ \\
\hline 503-m3 & & $25-41$ & $\mathrm{TL}$ & $\mathrm{h}$ Frit & $26-38$ & lvisc & $\mathrm{hFrit}$ & 26-39 & lvisc \\
\hline 503-m4 & & $25-42$ & TL Neph & hFrit & $26-35$ & lvisc & $\mathrm{hFrit}$ & $26-36$ & lvisc \\
\hline 503-m5 & & $25-38$ & lvisc & $\mathrm{hFrit}$ & 26-31 & lvisc & hFrit & 26-32 & lvisc \\
\hline 503-m6 & & $25-41$ & TL lvisc & $\mathrm{h}$ Frit & 26-33 & lvisc & $\mathrm{hFrit}$ & 26-34 & lvisc \\
\hline $503-\mathrm{m} 7$ & & $25-31$ & lvisc & & - & lvisc & & - & lvisc \\
\hline 503-m8 & & $25-38$ & $\mathrm{TL}$ & $\mathrm{hFrit}$ & $26-44$ & Neph & $\mathrm{hFrit}$ & $26-45$ & Neph \\
\hline 503-m9 & & 25-39 & $\mathrm{TL}$ & $\mathrm{h}$ Frit & $26-43$ & Neph & $\mathrm{hFrit}$ & $26-43$ & Neph \\
\hline $\mathrm{d} 1-1$ & & - & & hvisc & $34-47$ & hvisc & hvisc & $34-46$ & hvisc \\
\hline P1-1 & hvisc & 26-34 & $\mathrm{TL}$ & & $25-43$ & $\mathrm{TL}$ & & $25-42$ & $\mathrm{TL}$ \\
\hline P2-1 & & $25-36$ & $\mathrm{TL}$ & & $25-42$ & lvisc & & $25-43$ & lvisc \\
\hline P2-2 & & $25-36$ & $\mathrm{TL}$ & & $25-34$ & lvisc & & $25-35$ & lvisc \\
\hline P2-3 & & $25-38$ & $\mathrm{TL}$ & & $25-41$ & lvisc & & $25-42$ & lvisc \\
\hline P2-4 & & $25-37$ & TL lvisc & & $25-30$ & lvisc & & $25-31$ & lvisc \\
\hline P2-5 & & $25-37$ & $\mathrm{TL}$ & & $25-33$ & lvisc & & $25-34$ & lvisc \\
\hline P3-1/502 & & $25-42$ & $\mathrm{TL}$ & hFrit & $26-44$ & lvisc & $\mathrm{hFrit}$ & $26-45$ & lvisc \\
\hline P3-2 & & $25-41$ & $\mathrm{TL}$ & & $25-44$ & lvisc & & $25-45$ & $\begin{array}{l}\text { lvisc } \\
\text { Neph }\end{array}$ \\
\hline P3-3 & & $25-42$ & $\mathrm{TL}$ & & $25-41$ & lvisc & & $25-42$ & lvisc \\
\hline P3-4 & & $25-43$ & $\mathrm{TL}$ & $\mathrm{h}$ Frit & $26-43$ & lvisc & $\mathrm{hFrit}$ & $26-44$ & lvisc \\
\hline $\mathrm{t} 1-1$ & hvisc & $32-36$ & $\mathrm{TL}$ & & $25-46$ & $\mathrm{TL}$ & hvisc & $26-44$ & $\mathrm{TL}$ \\
\hline $\mathrm{X} 1-1$ & Del Gp & $27-33$ & lvisc & & - & Del Gp & & - & Del Gp \\
\hline Y1-1 & & $25-38$ & lvisc & & - & Del Gp & & - & Del Gp \\
\hline
\end{tabular}

Given a specific interest in Frit 418 and Frit 503, the rows of Table 4-1 showing the results for these two frits are shaded. Prior to assessing their potential use with the 10-04-06 composition, a brief review of the projected operating windows for the June projections is warranted to establish a technical basis for the impact of the recent compositional changes. For the Frit 418 systems, the two previous compositions yielded projected operating windows of $26-44 \%$ WL with each system being nepheline limited at higher WLs. The high content of $\mathrm{Na}_{2} \mathrm{O}$ in both the sludge and the frit drove the system to be nepheline limited - a condition which DWPF may wish to avoid as it relates to a waste form affecting property. For the two Frit 503 systems, the projected operating windows in terms of WL were $26-46 \%$ and $25-45 \%$, with the systems being either $\mathrm{T}_{\mathrm{L}}$ 
/nepheline or $\mathrm{T}_{\mathrm{L}}$ limited. The lower $\mathrm{Na}_{2} \mathrm{O}$ content of Frit 503 (relative to Frit 418) for a fixed $\mathrm{Na}_{2} \mathrm{O}$ sludge content increased $\mathrm{T}_{\mathrm{L}}$ predictions resulting in a shift from a purely nepheline limited system (Frit 418 systems) to one controlled primarily by $\mathrm{T}_{\mathrm{L}}$.

Based on the lower $\mathrm{Na}_{2} \mathrm{O}$ and higher $\mathrm{Fe}_{2} \mathrm{O}_{3}$ concentrations in the 10-04-06 composition (as compared to the June compositions), $\mathrm{T}_{\mathrm{L}}$ predictions would be expected to increase for a given frit at a fixed WL. This being the case, for systems that are $T_{L}$ limited (e.g., the two Frit 503 systems based on previous projections), $\mathrm{T}_{\mathrm{L}}$ predictions should further reduce the projected operating windows (assuming a compositional adjustment to the frit is not made). This was indeed the case as the projected operating window for the Frit 503-10-04-06 SB4 system was $25-37 \% \mathrm{WL}$, with the system being $\mathrm{T}_{\mathrm{L}}$ limited. Given the lower $\mathrm{Na}_{2} \mathrm{O}$ concentration in the 10-04-06 sludge, the $\mathrm{Na}_{2} \mathrm{O}$ content could easily be remedied by increasing the $\mathrm{Na}_{2} \mathrm{O}$ content in the frit (i.e., $4 \%$ in Frit 503 to $8 \%$ in Frit 418 ), which would reduce $\mathrm{T}_{\mathrm{L}}$ predictions and provide access to higher WLs. As a result, the projected operating window for the Frit $418-10-04-06$ SB4 system is $25-42 \%$ WL with the system still being $\mathrm{T}_{\mathrm{L}}$ limited. A continued increase in the $\mathrm{Na}_{2} \mathrm{O}$ content of the frit (e.g., 10\% in Frit 425) provides a $25-44 \%$ WL projected operating window - comparable to the previous higher $\mathrm{Na}_{2} \mathrm{O}$-based SB4 sludges when coupled with Frit 503. For the Frit 425 based system, both $\mathrm{T}_{\mathrm{L}}$ and nepheline limit access to higher WLs indicating that further increases in $\mathrm{Na}_{2} \mathrm{O}$ would drive the system into a nepheline limited situation and upper WLs would decrease from the $44 \%$ level.

Thus, strictly from the perspective of a projected operating window for the nominal composition, Frit 418 is more attractive than Frit 503 for the 10-04-06 SB4 projected composition. However, this comparison does not reflect other aspects of interest for the glass systems such as their respective melt rates. For example, the lower $\mathrm{B}_{2} \mathrm{O}_{3}$ content of Frit 418 relative to Frit $503(8 \%$ versus $14 \%$ ) may counter or off-set any positive melt rate impacts of the higher $\mathrm{Na}_{2} \mathrm{O}$ concentrations. In fact, Frit 503-m4 (see Table 3-1) was designed specifically for the 10-04-06 SB4 composition with the intent of balancing the $\mathrm{Na}_{2} \mathrm{O}$ content as well as maintaining relatively high $\mathrm{B}_{2} \mathrm{O}_{3}$ concentrations that were effective in terms of nepheline suppression and melt rate enhancements in recent experimental work. Based on the MAR assessments, Frit 503-m4 has a projected operating window of $25-42 \% \mathrm{WL}$ with the system being both $\mathrm{T}_{\mathrm{L}}$ and nepheline limited at 43\% WL (see Table 4-1). 
WSRC-STI-2006-00305

Revision 0

This page intentionally left blank. 


\subsection{Variation Stage Assessment - the Approach and the Results}

Since the Nominal Stage assessment does not account for any anticipated compositional variation in the sludge projection, there is an increased risk with respect to processability or product quality if a decision (i.e., frit selection) were to be based solely on this assessment. The risk is reduced by the Variation Stage assessment, which is used to gain insight into the robustness of candidate frits with respect to sludge compositional variation. For this analysis, a Variation Stage assessment was conducted for the 10-10-06 SB4 projection with Frit 418. ${ }^{\mathrm{a}}$ Table 5-1 provides the framework for the Variation Stage assessment for the sludge being evaluated. In this assessment, the nominal value for each oxide in the sludge is replaced with an interval, limited by a minimum (min) and maximum (max), of possible values. The second column of this table indicates the types of variation that were introduced to determine the minimums and maximums: a variation of $\pm 7.5 \%$ of the nominal value was used to determine the min's and max's for the major oxides (i.e., $\mathrm{Al}_{2} \mathrm{O}_{3}, \mathrm{Fe}_{2} \mathrm{O}_{3}, \mathrm{Na}_{2} \mathrm{O}$, and $\left.\mathrm{U}_{3} \mathrm{O}_{8}\right) . \mathrm{A} \pm 0.25 \mathrm{wt} \%$ variation was placed around the nominal value for each individually tracked minor oxide (i.e., $\mathrm{CaO}, \mathrm{MgO}, \mathrm{MnO}, \mathrm{NiO}$, and $\mathrm{SiO}_{2}$, but not $\mathrm{SO}_{4}{ }^{2-}$ ) and for "Others." The variation applied to the nominal $\mathrm{SO}_{4}{ }^{2-}$ value was $\pm 0.10 \mathrm{wt} \%$. The "Others" term was used to allow for the inclusion of the minor oxides that were not tracked individually. The composition of the "Others" component for each of the sludge options considered in this report was the same as used in the SB4/Frit $503 \mathrm{VS}^{17}$ and is provided (each oxide is given as a weight percentage of "Others") in Table 5-2.

Table 5-1. Nominal 10-10-06 SB4 Composition Projection and Sludge Composition Space with Traditional Variation Applied.

\begin{tabular}{|c|c|c|c|c|}
\hline \multirow[t]{2}{*}{$\begin{array}{c}\text { Oxide } \\
\text { Component }\end{array}$} & \multirow[t]{2}{*}{$\begin{array}{l}\text { Variation to be Applied } \\
\text { (Traditional Variation) }\end{array}$} & \multirow{2}{*}{$\begin{array}{c}\begin{array}{c}10-10-06 \\
\text { Projected SB4 } \\
\text { nominal } \\
\text { composition }\end{array} \\
(w t \%)\end{array}$} & \multicolumn{2}{|c|}{$\begin{array}{c}\text { 10-10-06 } \\
\text { Projected SB4 } \\
\text { with variation applied }\end{array}$} \\
\hline & & & $\min (w t \%)$ & $\max (w t \%)$ \\
\hline $\mathrm{Al}_{2} \mathrm{O}_{3}$ & $7.5 \%$ & 25.49 & 23.578 & 27.402 \\
\hline $\mathrm{CaO}$ & $0.25 \mathrm{wt} \%$ & 2.765 & 2.515 & 3.015 \\
\hline $\mathrm{Fe}_{2} \mathrm{O}_{3}$ & $7.5 \%$ & 28.989 & 26.814 & 31.163 \\
\hline $\mathrm{MgO}$ & $0.25 \mathrm{wt} \%$ & 2.774 & 2.524 & 3.024 \\
\hline $\mathrm{MnO}$ & $0.25 \mathrm{wt} \%$ & 5.783 & 5.350 & 6.217 \\
\hline $\mathrm{Na}_{2} \mathrm{O}$ & $7.5 \%$ & 18.708 & 17.304 & 20.111 \\
\hline $\mathrm{NiO}$ & $0.25 \mathrm{wt} \%$ & 1.66 & 1.410 & 1.910 \\
\hline $\mathrm{SO}_{4}$ & $0.1 \mathrm{wt} \%$ & 0.866 & 0.766 & 0.966 \\
\hline $\mathrm{SiO}_{2}$ & $0.25 \mathrm{wt} \%$ & 2.711 & 2.461 & 2.961 \\
\hline $\mathrm{U}_{3} \mathrm{O}_{8}$ & $7.5 \%$ & 9.031 & 8.354 & 9.709 \\
\hline Others & $0.25 \mathrm{wt}^{\circ} \%$ & 1.500 & 1.250 & 1.750 \\
\hline
\end{tabular}

\footnotetext{
a As previously noted, decisions regarding the use of Frit 418 were made prior to the receipt of the 10-10-06 composition. Therefore, the Variation Stage was performed utilizing only Frit 418 with the 10-10-06 composition.
} 
WSRC-STI-2006-00305

Revision 0

Table 5-2. Components Making up Others.

\begin{tabular}{|c|c||}
\hline $\begin{array}{c}\text { Minor } \\
\text { Component }\end{array}$ & $\begin{array}{c}\text { Percent of } \\
\text { Others }\end{array}$ \\
\hline $\mathrm{BaO}$ & 8.335 \\
\hline $\mathrm{Ce}_{2} \mathrm{O}_{3}$ & 10.088 \\
\hline $\mathrm{Cr}_{2} \mathrm{O}_{3}$ & 13.975 \\
\hline $\mathrm{CuO}$ & 4.028 \\
\hline $\mathrm{K}_{2} \mathrm{O}$ & 22.153 \\
\hline $\mathrm{La}_{2} \mathrm{O}_{3}$ & 7.123 \\
\hline $\mathrm{PbO}$ & 6.099 \\
\hline $\mathrm{ThO}_{2}$ & 4.22 \\
\hline $\mathrm{TiO}_{2}$ & 1.757 \\
\hline $\mathrm{ZnO}$ & 6.576 \\
\hline $\mathrm{ZrO}$ & 15.645 \\
\hline $\mathrm{Others}$ & 100 \\
\hline
\end{tabular}

Table 5-1 and Table 5-2 provide the framework around which the Variation Stage assessment was conducted. A sludge composition is in the region corresponding to the 10-10-06 projection if its concentration for each oxide is within the min and max interval for that oxide (e.g., the $\mathrm{Al}_{2} \mathrm{O}_{3}$ concentration in the sludge as a wt $\%$ is between 23.578 and 27.402) and the sum of the concentrations of all of the oxides in the sludge equals $100 \%$. Such a composition is a mixture of oxides at concentrations that correspond to one of the possible compositions for the sludge projection as defined by Table 5-1. Algorithms are available in statistical software packages such as JMP Version 6.0.2 $2^{27}$ to generate the compositions that are the "corner points" of the bounding sludge region defined by Table 5-1. The bounding "corner-point" compositions generated by JMP are called the extreme vertices (EVs) of the sludge region.

JMP Version 6.0.2 $2^{27}$ was used to generate the EVs or corner points of the sludge regions defined by the information in Table 5-1. For the "Others" component, the concentration for an EV was generated by JMP. This concentration was then exploded into the oxides comprising "Others" using the percentages of Table 5-2. The centroid (or average of the EVs) for the sludge region was also generated so that it may be tracked during the Variation Stage to ensure consistent results with the Nominal Stage assessment. ${ }^{\mathrm{a}}$

The EVs of the 10-10-06 SB4 projection that were generated by JMP were combined with Frit 418 at waste loadings from 25 to $60 \%$. The resulting glass compositions were evaluated against the PCCS MAR criteria to determine their respective acceptability. A frit is considered to demonstrate robustness to the variation in a sludge option if $100 \%$ of the EVs for the option meet the PCCS MAR criteria over a wide sub-interval of the 25 to $60 \% \mathrm{WL}$ interval. In addition, where less than $100 \%$ of the EVs are acceptable, identification of the constraint or constraints that are not met (i.e., the constraint(s) that limit the operating window) is of interest. The results of this evaluation for the centroid and for the EVs are provided in Table 5-3.

\footnotetext{
a It should be noted that the nominal composition was the 10-04-06 composition and the centroid are not the "exact" composition but will be extremely close. Therefore, the projected operating windows resulting from each should be relatively close in size.
} 
WSRC-STI-2006-00305

Revision 0

Table 5-3. MAR Results for the Centroid and Percent of EVs that Satisfy the MAR for the 10-10-06 SB4 Projection with Frit 418.

\begin{tabular}{|c|c|c|}
\hline$\% \mathrm{WL}$ & MAR Status for the Centroid & $\%$ of EVs \\
\hline 25 & & 100.0 \\
\hline 26 & & 100.0 \\
\hline 27 & & 100.0 \\
\hline 28 & & 100.0 \\
\hline 29 & & 100.0 \\
\hline 30 & & 100.0 \\
\hline 31 & & 100.0 \\
\hline 32 & & 100.0 \\
\hline 33 & & 100.0 \\
\hline 34 & & 100.0 \\
\hline 35 & & 100.0 \\
\hline 36 & & 100.0 \\
\hline 37 & & 100.0 \\
\hline 38 & & 100.0 \\
\hline 39 & & 99.8 \\
\hline 40 & & 91.8 \\
\hline 41 & & $\overline{73.9}$ \\
\hline 42 & & 55.4 \\
\hline 43 & $\frac{\mathrm{T}_{\mathrm{L}}}{\mathrm{s}}$ & 43.7 \\
\hline 44 & $\mathrm{~T}_{\mathrm{L}}$ & 31.7 \\
\hline 45 & $\mathrm{~T}_{\mathrm{L}}$ & 9.3 \\
\hline 46 & $\mathrm{~T}_{\mathrm{L}}$ & 1.1 \\
\hline 47 & $\mathrm{~T}_{\mathrm{L}}$ Neph & \\
\hline 48 & $\mathrm{~T}_{\mathrm{L}} \mathrm{Neph}$ & \\
\hline 49 & $\mathrm{~T}_{\mathrm{L}} \mathrm{Neph}$ & \\
\hline 50 & $T_{L}$ Neph & \\
\hline 51 & $T_{L}$ Neph & \\
\hline 52 & $\mathrm{~T}_{\mathrm{L}} \mathrm{Neph}$ & \\
\hline 53 & $\mathrm{~T}_{\mathrm{L}} \mathrm{Neph}$ & \\
\hline 54 & $\mathrm{~T}_{\mathrm{L}}$ Neph & \\
\hline 55 & $\mathrm{~T}_{\mathrm{L}}$ Neph & \\
\hline 56 & $\mathrm{~T}_{\mathrm{L}}$ Neph & \\
\hline 57 & $\mathrm{~T}_{\mathrm{L}}$ lvisc Neph & \\
\hline 58 & $T_{L}$ lvisc Neph & \\
\hline 59 & $T_{L}$ lvisc Neph & \\
\hline 60 & $\mathrm{~T}_{\mathrm{L}}$ lvisc Neph & \\
\hline
\end{tabular}

As with the Nominal Stage assessment which utilized the 10-04-06 SB4 projection, the 10-10-06 SB4/Frit 418 glass system is $T_{L}$ limited. The centroid of the Variation Stage assessment is limited to WLs less than $43 \%$ (i.e., a projected operating window from $25-42 \% \mathrm{WL}$ - consistent with the Nominal Stage results using the 10-04-06 projection with Frit 418). The yellow shading in Table 5-3 shows the WLs for which the nepheline constraint is not satisfied at the MAR. For the centroid, the nepheline constraint MAR is not satisfied at WLs of $47 \%$ and greater. With respect to the EVs, $T_{L}$ limits some of the EVs $\left(0.2 \%\right.$ fail the $\left.\mathrm{T}_{\mathrm{L}} \mathrm{MAR}\right)$ at a WL of $39 \%$ and some EVs fail the nepheline constraint MAR at a WL of $45 \%$.

Based on this assessment using the SB4 projection from 10-10-06, Frit 418 should allow access to WLs of interest (up to $42 \%$ based on the centroid composition) and demonstrates a relatively high degree of robustness to potential compositional variation (i.e., all of the EVs are MAR 
acceptable from $25-38 \% \mathrm{WL}$ ). In fact, for those EVs in the $39-44 \% \mathrm{WL}$ interval, only $\mathrm{T}_{\mathrm{L}}$ is restrictive which, if encountered during SME acceptability decisions, could be viewed as a management risk based decision. More specifically, nepheline formation and its potential impact to a waste form affecting property (durability) is not an issue at WLs of interest in the system. As previously mentioned, a potential disadvantage of Frit 418 could be associated with melt rate. Previous testing indicated a significantly lower melt rate with Frit 418 as compared to Frit 503, even with the higher $\mathrm{Na}_{2} \mathrm{O}$ based SB4 compositional projections received in June $2006 .{ }^{8}$ 
WSRC-STI-2006-00305

Revision 0

\subsection{Variability Study for the New SB4 Projection}

The glass region for the SB4/Frit 503 VS was determined ${ }^{17}$ using the June 2006 predictions of the composition of this sludge batch that led to SRNL's frit recommendation report. ${ }^{1}$ Variation was introduced into the composition of the sludge for the study to account for some of the uncertainty that may be present in these predictions as well as for process variation that may be experienced at the DWPF during its normal operations. From the frit perspective, the primary focus was on the use of Frit 503, as this frit was recommended for SB4 processing. ${ }^{1}$ However, the recommendation report also stated that Frit 418 was a viable option for DWPF processing during the transition from SB3 to SB4 (i.e. an acceptable product can be produced with both SB3 and SB4 when Frit 418 is used). ${ }^{a}$ As a result, some glasses from the SB4/Frit 418 system were also included in the variability study.

Do the glasses that were already batched, fabricated, and tested based on the June 2006 composition provide any support for the variability study corresponding to the 10-10-06 SB4/Frit 418 glass system? Table 6-1 was prepared to help address this question.

This table shows the interval of "coverage" for each of the major oxides for the glass system driving the SB4/Frit 503 VS as well as corresponding intervals for the glass system involving the 10-10-06 SB4 projection with Frit 418. For both cases, the intervals are determined for WLs from 25 to $45 \%$ (given the $\mathrm{T}_{\mathrm{L}}$ limitations shown in Table 5-3). While there is some overlap of select major oxides $\left(\mathrm{Al}_{2} \mathrm{O}_{3}, \mathrm{Fe}_{2} \mathrm{O}_{3}, \mathrm{Na}_{2} \mathrm{O}, \mathrm{SiO}_{2}\right.$, and $\left.\mathrm{U}_{3} \mathrm{O}_{8}\right)$, the primary difference is associated with $\mathrm{B}_{2} \mathrm{O}_{3}$. There is no overlap of the SB4/Frit 503 system with the 10-10-06 SB4/Frit 418 system over the WLs of interest given the significant differences in $\mathrm{B}_{2} \mathrm{O}_{3}$ content of the frit $(8 \%$ versus $14 \%$ ). What does this mean for the need to perform a supplemental variability study for the 10-10-06 SB4/Frit 418 region of interest? Unless there are historical glasses within the current databases that could be used to adequately cover the glass region of interest, a separate matrix would be required.

\footnotetext{
${ }^{a}$ Frit 503 was recommended for the majority of SB4 processing since this higher $\mathrm{B}_{2} \mathrm{O}_{3}$-containing frit has advantages over Frit 418 in melt rate and is less prone to nepheline crystallization.
} 
Table 6-1 Projected Glass Space (Mins and Maxs) for the 10-10-06 Projection/Frit Systems (over 25 - 45\% WL).

\begin{tabular}{|c|c|c|c|c|c|c|c|c|c|c|c|c|c|}
\hline & $\mathrm{Al}_{2} \mathrm{O}_{3}$ & $\mathrm{~B}_{2} \mathrm{O}_{3}$ & $\mathrm{CaO}$ & $\mathrm{Fe}_{2} \mathrm{O}_{3}$ & $\mathrm{Li}_{2} \mathrm{O}$ & $\mathrm{MgO}$ & $\mathrm{MnO}$ & $\mathrm{Na}_{2} \mathrm{O}$ & $\mathrm{NiO}$ & $\mathrm{SO}_{4}$ & $\mathrm{SiO}_{2}$ & $\mathrm{U}_{3} \mathrm{O}_{8}$ & \\
\hline Previous SB4 VS with & 0.05250 & 0.07700 & 0.00500 & 0.06000 & 0.04400 & 0.00500 & 0.01250 & 0.08250 & 0.00250 & 0.00250 & 0.42050 & 0.01750 & Min \\
\hline Frit $503(25-45 \% \mathrm{WL})$ & 0.11700 & 0.10500 & 0.01350 & 0.13050 & 0.06000 & 0.01350 & 0.02700 & 0.13900 & 0.00900 & 0.00900 & 0.56750 & 0.03600 & Max \\
\hline Blend 10-10-06 with & 0.05895 & 0.04400 & 0.00629 & 0.06704 & 0.04400 & 0.00631 & 0.01383 & 0.10326 & 0.00352 & 0.00192 & 0.42908 & 0.02195 & Min \\
\hline Frit $418(25-45 \% \mathrm{WL})$ & 0.12331 & 0.06000 & 0.01357 & 0.14023 & 0.06000 & 0.01361 & 0.02715 & 0.13450 & 0.00859 & 0.00435 & 0.57740 & 0.04177 & $\operatorname{Max}$ \\
\hline
\end{tabular}

Green: complete overlap

Yellow: some overlap exists (varying degrees)

Red: no overlap exists 
In looking to the results from previous SB4 glass studies, ${ }^{12-14,16}$ as well as existing glasses within the $\mathrm{ComPro}^{28}$ and nepheline ${ }^{29}$ databases, seven glasses had targeted compositions that reflected sludge contributions (independent of frit composition) at WLs in the interval of 28 to $45 \%$. These glasses are all from Phase 3 of the nepheline study ${ }^{13}$ and their targeted compositions are provided in Table 6-2. The durability of each of these glasses was acceptable and predictable. ${ }^{13}$ Although within the compositional region of interest, there is inadequate data in hand to technically defend the applicability of the current durability models to the Frit 418-10-10-06 SB4 compositional region of interest. More specifically, the seven glasses provide inadequate coverage of the compositional region of interest.

Table 6-2. Historical Glasses with Sludge Compositions Similar to the Revised SB4 projection.

\begin{tabular}{|c|c|c|c|c|c|c|c|}
\hline Frit & Frit 418 & Frit 501 & Frit 501 & Frit 501 & Frit 502 & Frit 502 & Frit 502 \\
\hline Glass ID & NEPH3-41 & NEPH3-45 & NEPH3-46 & NEPH3-47 & NEPH3-53 & NEPH3-54 & NEPH3-55 \\
\hline $\mathrm{Al}_{2} \mathrm{O}_{3}$ & 8.682 & 8.682 & 9.922 & 11.659 & 8.682 & 9.922 & 11.907 \\
\hline $\mathrm{B}_{2} \mathrm{O}_{3}$ & 5.200 & 5.850 & 5.400 & 4.770 & 5.200 & 4.800 & 4.160 \\
\hline $\mathrm{BaO}$ & 0.044 & 0.044 & 0.050 & 0.059 & 0.044 & 0.050 & 0.061 \\
\hline $\mathrm{CaO}$ & 0.836 & 0.836 & 0.955 & 1.122 & 0.836 & 0.955 & 1.146 \\
\hline $\mathrm{Ce}_{2} \mathrm{O}_{3}$ & 0.052 & 0.052 & 0.060 & 0.070 & 0.052 & 0.060 & 0.072 \\
\hline $\mathrm{Cr}_{2} \mathrm{O}_{3}$ & 0.074 & 0.074 & 0.085 & 0.100 & 0.074 & 0.085 & 0.102 \\
\hline $\mathrm{CuO}$ & 0.021 & 0.021 & 0.024 & 0.028 & 0.021 & 0.024 & 0.029 \\
\hline $\mathrm{Fe}_{2} \mathrm{O}_{3}$ & 9.298 & 9.298 & 10.626 & 12.486 & 9.298 & 10.626 & 12.751 \\
\hline $\mathrm{K}_{2} \mathrm{O}$ & 0.120 & 0.120 & 0.138 & 0.162 & 0.120 & 0.138 & 0.165 \\
\hline $\mathrm{La}_{2} \mathrm{O}_{3}$ & 0.038 & 0.038 & 0.043 & 0.051 & 0.038 & 0.043 & 0.052 \\
\hline $\mathrm{Li}_{2} \mathrm{O}$ & 5.200 & 6.500 & 6.000 & 5.300 & 7.150 & 6.600 & 5.720 \\
\hline $\mathrm{MgO}$ & 0.873 & 0.873 & 0.998 & 1.173 & 0.873 & 0.998 & 1.198 \\
\hline $\mathrm{MnO}$ & 1.918 & 1.918 & 2.192 & 2.576 & 1.918 & 2.192 & 2.630 \\
\hline $\mathrm{Na}_{2} \mathrm{O}$ & 12.928 & 10.978 & 11.832 & 13.027 & 10.978 & 11.832 & 13.198 \\
\hline $\mathrm{NiO}$ & 0.552 & 0.552 & 0.631 & 0.741 & 0.552 & 0.631 & 0.757 \\
\hline $\mathrm{PbO}$ & 0.032 & 0.032 & 0.036 & 0.043 & 0.032 & 0.036 & 0.043 \\
\hline $\mathrm{SO}_{4}{ }^{2-}$ & 0.468 & 0.468 & 0.535 & 0.629 & 0.468 & 0.535 & 0.642 \\
\hline $\mathrm{SiO}_{2}$ & 50.840 & 50.840 & 47.245 & 42.213 & 50.840 & 47.245 & 41.494 \\
\hline $\mathrm{ThO}_{2}$ & 0.023 & 0.023 & 0.026 & 0.031 & 0.023 & 0.026 & 0.032 \\
\hline $\mathrm{TiO}_{2}$ & 0.009 & 0.009 & 0.011 & 0.013 & 0.009 & 0.011 & 0.013 \\
\hline $\mathrm{U}_{3} \mathrm{O}_{8}$ & 2.674 & 2.674 & 3.056 & 3.591 & 2.674 & 3.056 & 3.667 \\
\hline $\mathrm{ZnO}$ & 0.034 & 0.034 & 0.039 & 0.046 & 0.034 & 0.039 & 0.047 \\
\hline $\mathrm{ZrO}_{2}$ & 0.083 & 0.083 & 0.095 & 0.111 & 0.083 & 0.095 & 0.114 \\
\hline
\end{tabular}

In discussions with Waste Solidification Engineering (WS-E) of the results being presented in this report, their decision was for SRNL to focus the next phase of the variability study on the use of Frit 418 with the 10-10-06 SB4 composition to reduce the risk associated with processing this glass system. Selecting these glasses is pursued in the next section. 
WSRC-STI-2006-00305

Revision 0

This page intentionally left blank. 


\subsection{Selecting Target Compositions of Selected Glasses}

The information of Table 5-1 was used to define the sludge region from which the glasses for the supplemental SB4/Frit 418 VS were to be selected. Initially, the Design of Experiment platform's Custom Design feature of JMP Version 6.0.2 was used to select 11 sludge compositions satisfying the concentration intervals of Table 5-1. This JMP feature allows the user to specify the form of a model such as a linear model consisting of a term for each of the 11 oxides of Table 5-1 (including "Others"). Then JMP's coordinate exchange algorithm was used to optimally select a specified number of design points, $n$ (where $n \geq 11$ ), for this model from the region defined by the intervals of Table 5-1, with the intervals being specified in JMP during the design activity. The optimality criterion used in this case was D-optimality, which has the goal of minimizing $\left|\left(\mathrm{X}^{\mathrm{T}} \mathrm{X}\right)^{-1}\right|$, where $\mathrm{X}$ is the design matrix, $\mathrm{X}^{\mathrm{T}}$ indicates the transpose of $\mathrm{X},\left(\mathrm{X}^{\mathrm{T}} \mathrm{X}\right)^{-1}$ indicates the matrix inversion of the product of $X^{T}$ and $X$, and $\left|\left(X^{T} X\right)^{-1}\right|$ represents the determinant of the matrix $\left(\mathrm{X}^{\mathrm{T}} \mathrm{X}\right)^{-1}$. In the task, the number of design points, $n$, was taken to be its smallest possible value, 11. The 11 sludge EVs selected by this process are given in Table 7-1.

Table 7-1. D-Optimal Set of 11 Sludge EVs for Projected SB4 Composition with Variation.

\begin{tabular}{|c|c|c|c|c|c|c|c|c|c|c|c|}
\hline Type & EV-01 & EV-02 & EV-03 & EV-04 & EV-05 & EV-06 & EV-07 & EV-08 & EV-09 & EV-10 & EV-11 \\
\hline $\mathrm{Al}_{2} \mathrm{O}_{3}$ & 23.578 & 26.917 & 27.402 & 27.402 & 26.945 & 26.404 & 23.578 & 23.578 & 23.578 & 27.402 & 23.578 \\
\hline $\mathrm{BaO}$ & 0.103 & 0.103 & 0.146 & 0.146 & 0.146 & 0.103 & 0.103 & 0.146 & 0.146 & 0.103 & 0.146 \\
\hline $\mathrm{CaO}$ & 3.015 & 2.515 & 3.015 & 2.515 & 3.015 & 2.515 & 3.015 & 2.515 & 2.515 & 3.015 & 3.015 \\
\hline $\mathrm{Ce}_{2} \mathrm{O}_{3}$ & 0.125 & 0.125 & 0.177 & 0.177 & 0.177 & 0.125 & 0.125 & 0.177 & 0.177 & 0.125 & 0.177 \\
\hline $\mathrm{Cr}_{2} \mathrm{O}_{3}$ & 0.173 & 0.173 & 0.245 & 0.245 & 0.245 & 0.173 & 0.173 & 0.245 & 0.245 & 0.173 & 0.245 \\
\hline $\mathrm{CuO}$ & 0.050 & 0.050 & 0.070 & 0.070 & 0.070 & 0.050 & 0.050 & 0.070 & 0.070 & 0.050 & 0.070 \\
\hline $\mathrm{Fe}_{2} \mathrm{O}_{3}$ & 30.495 & 31.163 & 27.241 & 26.814 & 26.814 & 26.814 & 28.473 & 29.613 & 30.765 & 27.610 & 30.932 \\
\hline $\mathrm{K} 2 \mathrm{O}$ & 0.274 & 0.274 & 0.388 & 0.388 & 0.388 & 0.274 & 0.274 & 0.388 & 0.388 & 0.274 & 0.388 \\
\hline $\mathrm{La}_{2} \mathrm{O}_{3}$ & 0.088 & 0.088 & 0.125 & 0.125 & 0.125 & 0.088 & 0.088 & 0.125 & 0.125 & 0.088 & 0.125 \\
\hline $\mathrm{MgO}$ & 3.024 & 2.524 & 2.524 & 3.024 & 2.524 & 2.524 & 2.524 & 2.524 & 3.024 & 3.024 & 2.524 \\
\hline $\mathrm{MnO}$ & 5.350 & 5.350 & 6.217 & 5.350 & 5.350 & 5.350 & 6.217 & 6.217 & 6.217 & 6.217 & 5.350 \\
\hline $\mathrm{Na}_{2} \mathrm{O}$ & 20.111 & 17.304 & 17.304 & 18.299 & 20.111 & 20.111 & 20.111 & 20.111 & 17.304 & 17.304 & 17.304 \\
\hline $\mathrm{NiO}$ & 1.410 & 1.410 & 1.410 & 1.410 & 1.910 & 1.910 & 1.410 & 1.410 & 1.910 & 1.910 & 1.910 \\
\hline $\mathrm{PbO}$ & 0.075 & 0.075 & 0.107 & 0.107 & 0.107 & 0.075 & 0.075 & 0.107 & 0.107 & 0.075 & 0.107 \\
\hline $\mathrm{SO}_{4}{ }^{2-}$ & 0.966 & 0.766 & 0.966 & 0.766 & 0.766 & 0.966 & 0.766 & 0.966 & 0.766 & 0.966 & 0.966 \\
\hline $\mathrm{SiO}_{2}$ & 2.461 & 2.461 & 2.461 & 2.961 & 2.461 & 2.461 & 2.961 & 2.961 & 2.461 & 2.961 & 2.961 \\
\hline $\mathrm{ThO}_{2}$ & 0.052 & 0.052 & 0.074 & 0.074 & 0.074 & 0.052 & 0.052 & 0.074 & 0.074 & 0.052 & 0.074 \\
\hline $\mathrm{TiO}_{2}$ & 0.022 & 0.022 & 0.031 & 0.031 & 0.031 & 0.022 & 0.022 & 0.031 & 0.031 & 0.022 & 0.031 \\
\hline $\mathrm{U}_{3} \mathrm{O}_{8}$ & 8.354 & 8.354 & 9.709 & 9.709 & 8.354 & 9.709 & 9.709 & 8.354 & 9.709 & 8.354 & 9.709 \\
\hline $\mathrm{ZnO}$ & 0.081 & 0.081 & 0.115 & 0.115 & 0.115 & 0.081 & 0.081 & 0.115 & 0.115 & 0.081 & 0.115 \\
\hline $\mathrm{ZrO}_{2}$ & 0.193 & 0.193 & 0.274 & 0.274 & 0.274 & 0.193 & 0.193 & 0.274 & 0.274 & 0.193 & 0.274 \\
\hline
\end{tabular}

Each of these sludge EVs was combined with Frit 418 at WLs from 25 to $60 \%$ in 1\% increments. The resulting glass compositions were assessed against the PCCS MAR criteria, and the outcome is presented in Figure 7-1. The centroid shown in this exhibit was determined by averaging the 11 sludge EVs. The centroid was also combined with Frit 418 at WLs from 25 to $60 \%$. 


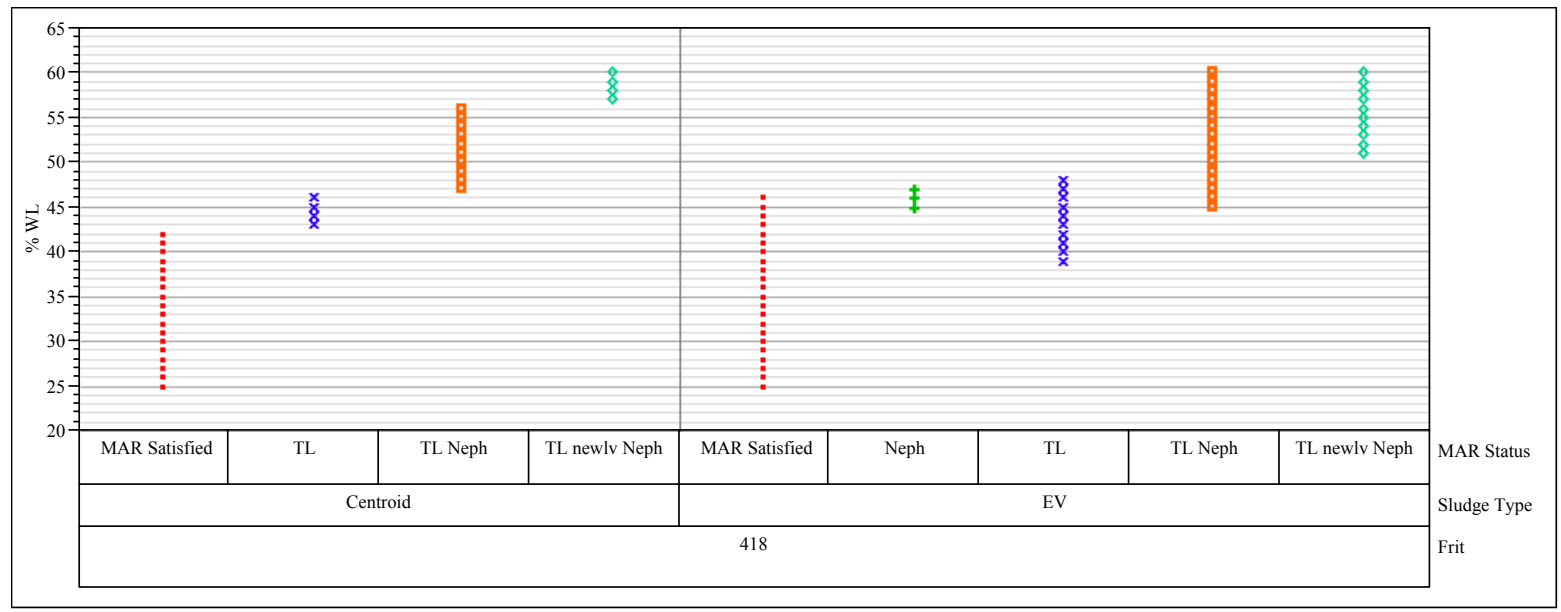

Figure 7-1. Assessment of PCCS MAR Criteria for SB4/Frit 418 Glasses.

All of the glass compositions corresponding to the points shown to meet the MAR criteria in Figure 7-1 (red blocks in the "MAR Satisfied" column) are candidate compositions for the SB4/Frit 418 variability study. Prior to selecting the specific glasses for the supplemental study, a brief review of the projected operating windows for the centroid and EV-based Frit 418 systems is warranted. For the centroid, the projected operating window is $25-42 \% \mathrm{WL}$ with $\mathrm{T}_{\mathrm{L}}$ prediction limiting access to higher WLs. All of the EVs can be processed over a WL interval of $25-38 \%$. This information is consistent with the results presented in Table 5-3.

A review of the results led to the selection of the combinations for the EVs and their centroid with Frit 418 at the WLs given in Table 7-2. The predictions for several of the processing and quality characteristics of these glasses are also provided in this table.

Table 7-2. Selected Glasses for the SB4/Frit 418 VS with Property Predictions.

\begin{tabular}{|c|c|c|c|c|c|c|c|}
\hline $\begin{array}{c}\text { WL } \\
(w t \%)\end{array}$ & Frit & Sludge Type & $\begin{array}{c}\Delta G_{p} \text { Value } \\
\text { (kcal/100 g } \\
\text { glass) }\end{array}$ & NL[B (g/L)] & $\begin{array}{c}\text { Liquidus } \\
\text { Temperature } \\
\text { Prediction }\left({ }^{\circ} \mathrm{C}\right)\end{array}$ & $\begin{array}{c}\text { Viscosity } \\
\text { Prediction (P) }\end{array}$ & $\begin{array}{c}\text { Nepheline } \\
\text { Discriminator } \\
\text { Value } \\
\end{array}$ \\
\hline 40 & 418 & EV-01 & -9.254 & 0.596 & 971.3 & 46.14 & 0.677 \\
\hline 34 & 418 & EV-02 & -7.944 & 0.345 & 935.2 & 74.18 & 0.715 \\
\hline 38 & 418 & EV-03 & -8.053 & 0.361 & 966.5 & 73.35 & 0.686 \\
\hline 38 & 418 & EV-04 & -8.249 & 0.392 & 961.1 & 70.77 & 0.684 \\
\hline 36 & 418 & EV-05 & -8.940 & 0.523 & 934.0 & 65.77 & 0.692 \\
\hline 28 & 418 & EV-06 & -9.042 & 0.546 & 823.7 & 81.60 & 0.747 \\
\hline 30 & 418 & EV-07 & -9.404 & 0.635 & 835.3 & 70.78 & 0.743 \\
\hline 42 & 418 & EV-08 & -9.345 & 0.619 & 989.2 & 43.67 & 0.663 \\
\hline 32 & 418 & EV-09 & -8.595 & 0.453 & 919.4 & 71.49 & 0.739 \\
\hline 34 & 418 & EV-10 & -8.152 & 0.376 & 932.2 & 81.60 & 0.714 \\
\hline 30 & 418 & EV-11 & -8.551 & 0.445 & 887.7 & 76.25 & 0.752 \\
\hline 32 & 418 & Centroid & -8.714 & 0.476 & 894.6 & 73.90 & 0.729 \\
\hline 36 & 418 & Centroid & -8.633 & 0.460 & 943.8 & 65.59 & 0.703 \\
\hline
\end{tabular}


The compositions for the centroid glasses are provided in Table 7-3. This pair of glasses is at WLs of 32 and $36 \%$, the primary WL interval of interest for this glass system.

Table 7-3. Target Glass Compositions for Frit 418 with the Centroid SB4 Composition (in wt\%).

\begin{tabular}{|c|c|c||}
\hline Glass ID & SB4VS-47 & SB4VS-48 \\
\hline $\mathbf{W L}$ & $\mathbf{3 2}$ & $\mathbf{3 6}$ \\
\hline $\mathrm{Al}_{2} \mathrm{O}_{3}$ & 8.134 & 9.151 \\
\hline $\mathrm{B}_{2} \mathrm{O}_{3}$ & 5.440 & 5.120 \\
\hline $\mathrm{BaO}$ & 0.040 & 0.045 \\
\hline $\mathrm{CaO}$ & 0.885 & 0.996 \\
\hline $\mathrm{Ce}_{2} \mathrm{O}_{3}$ & 0.048 & 0.054 \\
\hline $\mathrm{Cr}_{2} \mathrm{O}_{3}$ & 0.067 & 0.075 \\
\hline $\mathrm{CuO}$ & 0.019 & 0.022 \\
\hline $\mathrm{Fe}_{2} \mathrm{O}_{3}$ & 9.247 & 10.403 \\
\hline $\mathrm{K}_{2} \mathrm{O}$ & 0.106 & 0.119 \\
\hline $\mathrm{La}_{2} \mathrm{O}_{3}$ & 0.034 & 0.038 \\
\hline $\mathrm{Li}_{2} \mathrm{O}$ & 5.440 & 5.120 \\
\hline $\mathrm{MgO}_{\mathrm{MnO}}$ & 0.888 & 0.999 \\
\hline $\mathrm{MnO}$ & 1.851 & 2.082 \\
\hline $\mathrm{Na}_{2} \mathrm{O}$ & 11.384 & 11.807 \\
\hline $\mathrm{NiO}$ & 0.531 & 0.598 \\
\hline $\mathrm{PbO}^{2-}$ & 0.029 & 0.033 \\
\hline $\mathrm{SO}_{4}{ }^{2-}$ & 0.277 & 0.312 \\
\hline $\mathrm{SiO}_{2}$ & 52.548 & 49.616 \\
\hline $\mathrm{ThO}_{2}$ & 0.020 & 0.023 \\
\hline $\mathrm{TiO}_{2}$ & 0.008 & 0.009 \\
\hline $\mathrm{U}_{3} \mathrm{O}_{8}$ & 2.897 & 3.259 \\
\hline $\mathrm{ZnO}_{2 n O}$ & 0.031 & 0.035 \\
\hline $\mathrm{ZrO}_{2}$ & 0.075 & 0.084 \\
\hline
\end{tabular}

The compositions of the glasses derived from the EVs of the sludge region are given in Table 7-4. These glasses cover WLs from 28 to $42 \%$ with 8 falling within the WL interval from 30 to $38 \%$ (inclusive). 
Table 7-4. Target Glass Compositions for Frit 418 with the Inner Layer SB4 EVs (in wt\%).

\begin{tabular}{|c|c|c|c|c|c|c|c|c|c|c|c|}
\hline Glass ID & 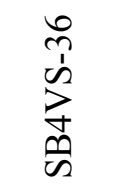 & $\begin{array}{l}\hat{m} \\
\dot{1} \\
\dot{m} \\
\dot{m}\end{array}$ & 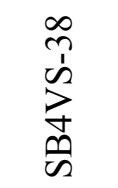 & 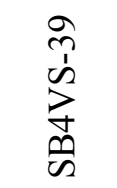 & 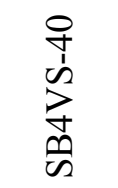 & 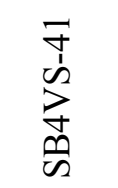 & 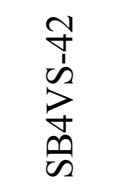 & 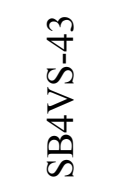 & 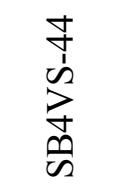 & 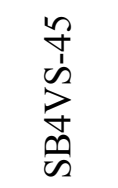 & 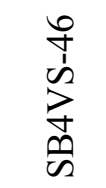 \\
\hline WL & 40 & 34 & 38 & 38 & 36 & 28 & 30 & 42 & 32 & 34 & 30 \\
\hline $\mathrm{Al}_{2} \mathbf{O}_{3}$ & 9.431 & 9.152 & 10.413 & 10.413 & 9.700 & 7.393 & 7.074 & 9.903 & 7.545 & 9.317 & 7.074 \\
\hline $\mathbf{B}_{2} \mathbf{O}_{3}$ & 4.800 & 5.280 & 4.960 & 4.960 & 5.120 & 5.760 & 5.600 & 4.640 & 5.440 & 5.280 & 5.600 \\
\hline $\mathrm{BaO}$ & 0.041 & 0.035 & 0.055 & 0.055 & 0.053 & 0.029 & 0.031 & 0.061 & 0.047 & 0.035 & 0.044 \\
\hline $\mathrm{CaO}$ & 1.206 & 0.855 & 1.146 & 0.956 & 1.085 & 0.704 & 0.905 & 1.056 & 0.805 & 1.025 & 0.905 \\
\hline $\mathrm{Ce}_{2} \mathrm{O}_{3}$ & 0.050 & 0.042 & 0.067 & 0.067 & 0.064 & 0.035 & 0.037 & 0.074 & 0.056 & 0.042 & 0.053 \\
\hline $\mathrm{Cr}_{2} \mathrm{O}_{3}$ & 0.069 & 0.059 & 0.093 & 0.093 & 0.088 & 0.048 & 0.052 & 0.103 & 0.078 & 0.059 & 0.073 \\
\hline $\mathrm{CuO}$ & 0.020 & 0.017 & 0.027 & 0.027 & 0.025 & 0.014 & 0.015 & 0.030 & 0.023 & 0.017 & 0.021 \\
\hline $\mathrm{Fe}_{2} \mathrm{O}_{3}$ & 12.198 & 10.595 & 10.352 & 10.189 & 9.653 & 7.508 & 8.542 & 12.438 & 9.845 & 9.387 & 9.280 \\
\hline $\mathbf{K}_{2} \mathbf{O}$ & 0.110 & 0.093 & 0.147 & 0.147 & 0.140 & 0.077 & 0.082 & 0.163 & 0.124 & 0.093 & 0.116 \\
\hline $\mathrm{La}_{2} \mathrm{O}_{3}$ & 0.035 & 0.030 & 0.047 & 0.047 & 0.045 & 0.025 & 0.026 & 0.052 & 0.040 & 0.030 & 0.037 \\
\hline $\mathbf{L i}_{2} \mathbf{O}$ & 4.800 & 5.280 & 4.960 & 4.960 & 5.120 & 5.760 & 5.600 & 4.640 & 5.440 & 5.280 & 5.600 \\
\hline MgO & 1.209 & 0.858 & 0.959 & 1.149 & 0.909 & 0.707 & 0.757 & 1.060 & 0.968 & 1.028 & 0.757 \\
\hline MnO & 2.140 & 1.819 & 2.363 & 2.033 & 1.926 & 1.498 & 1.865 & 2.611 & 1.989 & 2.114 & 1.605 \\
\hline $\mathrm{Na}_{2} \mathrm{O}$ & 12.844 & 11.164 & 11.536 & 11.914 & 12.360 & 11.391 & 11.633 & 13.086 & 10.977 & 11.164 & 10.791 \\
\hline $\mathrm{NiO}$ & 0.564 & 0.479 & 0.536 & 0.536 & 0.688 & 0.535 & 0.423 & 0.592 & 0.611 & 0.649 & 0.573 \\
\hline PbO & 0.030 & 0.026 & 0.041 & 0.041 & 0.038 & 0.021 & 0.023 & 0.045 & 0.034 & 0.026 & 0.032 \\
\hline $\mathrm{SO}_{4}$ & 0.387 & 0.261 & 0.367 & 0.291 & 0.276 & 0.271 & 0.230 & 0.406 & 0.245 & 0.329 & 0.290 \\
\hline $\mathrm{SiO}_{2}$ & 46.585 & 50.997 & 48.055 & 48.245 & 49.526 & 55.409 & 54.088 & 45.324 & 52.468 & 51.167 & 54.088 \\
\hline $\mathrm{ThO}_{2}$ & 0.021 & 0.018 & 0.028 & 0.028 & 0.027 & 0.015 & 0.016 & 0.031 & 0.024 & 0.018 & 0.022 \\
\hline $\mathrm{TiO}_{2}$ & 0.009 & 0.007 & 0.012 & 0.012 & 0.011 & 0.006 & 0.007 & 0.013 & 0.010 & 0.007 & 0.009 \\
\hline $\mathbf{U}_{3} \mathbf{O}_{8}$ & 3.342 & 2.840 & 3.689 & 3.689 & 3.007 & 2.718 & 2.913 & 3.509 & 3.107 & 2.840 & 2.913 \\
\hline $\mathrm{ZnO}$ & 0.033 & 0.028 & 0.044 & 0.044 & 0.041 & 0.023 & 0.024 & 0.048 & 0.037 & 0.028 & 0.035 \\
\hline $\mathrm{ZrO}_{2}$ & 0.077 & 0.066 & 0.104 & 0.104 & 0.099 & 0.054 & 0.058 & 0.115 & 0.088 & 0.066 & 0.082 \\
\hline
\end{tabular}




\subsection{Summary}

In early October 2006, the LWO began to consider decanting Tank 40 at the end of SB3 processing and transferring the aqueous phase from the decant to Tank 51. This is to facilitate the transfer of the contents of Tank 51 to Tank 40 by adjusting Tank 51 rheology to an acceptable level. The projected composition of SB4 was adjusted by LWO to reflect the impact of the Tank 40 decant leading to new projected compositions for SB4, designated as the 10-04-06 and the 1010-06 compositions. A comparison between these SB4 compositions and those provided in June 2006 indicates that the new compositions are slightly higher in $\mathrm{Al}_{2} \mathrm{O}_{3}, \mathrm{Fe}_{2} \mathrm{O}_{3}$, and $\mathrm{U}_{3} \mathrm{O}_{8}$ and slightly lower in $\mathrm{SiO}_{2}$. The most dramatic change, however, is the new projection's $\mathrm{Na}_{2} \mathrm{O}$ concentration, which is more than $4.5 \mathrm{wt} \%$ lower than the earlier projection. This is a significant change due to the frit development team's approach of aligning the $\mathrm{Na}_{2} \mathrm{O}$ concentration in a candidate frit to the $\mathrm{Na}_{2} \mathrm{O}$ content of the sludge. This approach enhances the projected operating window and the waste throughput potential for the resulting glass system while eliminating the potential for nepheline crystallization. Nepheline has a detrimental impact on durability.

Questions surfaced regarding the applicability of Frit 503 to these revised compositions since SRNL recommended Frit 503 for use with SB4 based on the June 2006 compositional projection. Based on the paper study assessments, the change in SB4's expected $\mathrm{Na}_{2} \mathrm{O}$ content had a significant, negative impact on the projected operating window for the Frit 503/SB4 glass system. While Frit 418 had slightly smaller WL intervals for the June 2006 SB4 projections as compared to Frit 503 and the Frit 418 glass systems were nepheline limited, Frit 418 has a slightly larger operating window for the 10-04-06 projection (as compared to Frit 503) and the Frit 418/10-0406 glass system is no longer nepheline limited. Thus, strictly from the perspective of this paper study, Frit 418 is more attractive than Frit 503 for the new SB4 projected compositions. However, this comparison does not reflect other aspects of interest for the glass systems such as their respective melt rates or the development of alternative frits to balance the projected operating windows, melt rate, waste throughput, and robustness to compositional variation.

In discussions with WS-E of the results being presented in this report, their decision was to utilize Frit 418 for initial processing of SB4. This decision was not only based on the paper study assessments presented in this report, but also on the fact that Frit 418 is currently being used to process SB3 and, perhaps more importantly, frit optimization efforts for SB4 may be premature given the uncertainties in sludge composition compounded by uncertainty in the tank transfer and heel volumes associated with the SB4 flowsheet. More specifically, WS-E plans to initiate processing with Frit 418 and will authorize the frit development team to optimize a frit once SB4 composition projections are more certain (i.e., the transfer volumes and masses are known and updated Tank 40 and Tank 51 compositions are available).

Given this decision and recognizing that a SB4/Frit 503 variability study had been initiated as part of the qualification process, questions regarding the need for a supplemental variability study to demonstrate applicability of the process control models for a Frit 418 based system surfaced. This report addresses the need for a supplemental study and defines additional glasses to fill the compositional gaps. A total of 13 glasses (based on the 10-10-06 projection) were selected for the supplemental SB4/Frit 418 variability study. These glasses will be batched and melted following standard SRNL procedures, and a suite of characterization testing will be completed to measure the chemical durability of each glass composition. A subsequent report will document the results of the experimental portion of the SB4/Frit 418 variability study. 
WSRC-STI-2006-00305

Revision 0

This page intentionally left blank. 
WSRC-STI-2006-00305

Revision 0

\subsection{References}

1. Peeler, D. K., T. B. Edwards and K. M. Fox, "Frit Recommendation for SB4," U.S. Department of Energy Report SRNL-PSE-2006-00128, Washington Savannah River Company, Aiken, South Carolina (2006).

2. Peeler, D. K. and T. B. Edwards, "Frit Development Effort for SB4: Nominal and Variation Stage Assessments," U.S. Department of Energy Report WSRC-TR-2005-00372, Revision 0, Westinghouse Savannah River Company, Aiken, South Carolina (2005).

3. Peeler, D. K. and T. B. Edwards, "The Impact of the Actinide Removal Process (ARP) on the Sludge Batch 4 Projected Operating Windows," U.S. Department of Energy Report WSRC-TR2005-00123, Revision 0, Westinghouse Savannah River Company, Aiken, South Carolina (2005).

4. Peeler, D. K. and T. B. Edwards, "Frit Development Efforts for Sludge Batch 4: Model-Based Assessments," U.S. Department of Energy Report WSRC-TR-2005-00103, Revision 0, Westinghouse Savannah River Company, Aiken, South Carolina (2005).

5. Peeler, D. K. and T. B. Edwards, "Model Based Assessments for the Baseline Sludge Batch 4 (Case 15C) Flowsheet," U.S. Department of Energy Report WSRC-TR-2006-00049, Revision 0, Washington Savannah River Company, Aiken, South Carolina (2006).

6. Peeler, D. K. and T. B. Edwards, "Model Based Assessments for SB4 Washing Options: 1.2M Batch/0.91M Blend and 1.4M Batch/0.96M Blend," U.S. Department of Energy Report WSRCSTI-2006-00006, Revision 0, Washington Savannah River Company, Aiken, South Carolina (2006).

7. Peeler, D. K. and T. B. Edwards, "High $\mathrm{B}_{2} \mathrm{O}_{3} / \mathrm{Fe}_{2} \mathrm{O}_{3}$-based Frits: MAR Assessments for Sludge Batch 4 (SB4)," U.S. Department of Energy Report WSRC-TR-2006-00181, Revision 0, Washington Savannah River Company, Aiken, South Carolina (2006).

8. Smith, M. E., M. E. Stone, T. M. Jones, D. H. Miller and P. R. Burket, "SB4 MRF and SMRF Tests with Frits 418, 425, and 503 (U)," U.S. Department of Energy Report WSRC-STI-200600015, Revision 0, Washington Savannah River Company, Aiken, South Carolina (2006).

9. Edwards, T. B. and D. K. Peeler, "Nepheline Formation Potential in Sludge Batch 4 (SB4) and Its Impact on Durability: Selecting Glasses for a Phase 2 Study," U.S. Department of Energy Report WSRC-TR-2005-00370, Revision 0, Westinghouse Savannah River Company, Aiken, South Carolina (2005).

10. Edwards, T. B., D. K. Peeler and K. M. Fox, "The Nepheline Discriminator: Justification and DWPF PCCS Implementation Details," U.S. Department of Energy Report WSRC-STI-200600014, Revision 0, Washington Savannah River Company, Aiken, South Carolina (2006).

11. Fox, K. M., T. B. Edwards and D. K. Peeler, "Nepheline Formation Potential in Sludge Batch 4 (SB4) and Its Impact on Durability: Selecting Glasses for a Phase 3 Study," U.S. Department of Energy Report WSRC-TR-2006-00053, Revision 0, Washington Savannah River Company, Aiken, South Carolina (2006).

12. Fox, K. M., T. B. Edwards, D. K. Peeler, D. R. Best, I. A. Reamer and R. J. Workman, "Durability and Nepheline Crystallization Study for High Level Waste (HLW) Sludge Batch 4 
WSRC-STI-2006-00305

Revision 0

(SB4) Glasses Formulated with Frit 503," U.S. Department of Energy Report WSRC-STI-200600009, Revision 0, Washington Savannah River Company, Aiken, South Carolina (2006).

13. Fox, K. M., D. K. Peeler, T. B. Edwards, D. R. Best, I. A. Reamer and R. J. Workman, "Nepheline Formation Study for Sludge Batch 4 (SB4): Phase 3 Experimental Results," U.S. Department of Energy Report WSRC-TR-2006-00093, Revision 0, Washington Savannah River Company, Aiken, South Carolina (2006).

14. Peeler, D. K., T. B. Edwards, D. R. Best, I. A. Reamer and R. J. Workman, "Nepheline Formation Study for Sludge Batch 4 (SB4): Phase 2 Experimental Results," U.S. Department of Energy Report WSRC-TR-2006-00006, Revision 0, Washington Savannah River Company, Aiken, South Carolina (2006).

15. Peeler, D. K., T. B. Edwards and T. H. Lorier, "Nepheline Formation Potential in Sludge Batch (SB4) Glasses," U.S. Department of Energy Report WSRC-TR-2005-00153, Revision 0, Westinghouse Savannah River Company, Aiken, South Carolina (2005).

16. Peeler, D. K., T. B. Edwards, I. A. Reamer and R. J. Workman, "Nepheline Formation Study for Sludge Batch 4 (SB4): Phase 1 Experimental Results," U.S. Department of Energy Report WSRC-TR-2005-00371, Revision 0, Westinghouse Savannah River Company, Aiken, South Carolina (2005).

17. Fox, K. M., T. B. Edwards and D. K. Peeler, "High Level Waste (HLW) Sludge Batch 4 (SB4): Selecting Glasses for a Variability Study," U.S. Department of Energy Report WSRC-STI2006-00039, Revision 0, Washington Savannah River Company, Aiken, South Carolina (2006).

18. Fox, K. M., T. B. Edwards, D. K. Peeler, D. R. Best, I. A. Reamer and R. J. Workman, "High Level Waste (HLW) Sludge Batch 4 (SB4) Variability Study," U.S. Department of Energy Report WSRC-STI-2006-00204, Revision 0, Washington Savannah River Company, Aiken, South Carolina (2006).

19. Jantzen, C. M., J. B. Picket, K. G. Brown, T. B. Edwards and D. C. Beam, "Process/Product Models for the Defense Waste Processing Facility (DWPF): Part I. Predicting Glass Durability from Composition Using a Thermodynamic Hydration Energy Reaction Model (THERMO)," U.S. Department of Energy Report WSRC-TR-93-672, Revision 1, Westinghouse Savannah River Company, Aiken, South Carolina (1995).

20. Shah, H. B., "Sludge Batch 4 Blend Ratio Determination," U.S. Department of Energy Report LWO-PIT-2006-00038, Revision 0, Washington Savannah River Company, Aiken, South Carolina (2006).

21. Peeler, D. K. and T. B. Edwards, "Frit Development for Sludge Batch 3," U.S. Department of Energy Report WSRC-TR-2002-00491, Revision 0, Westinghouse Savannah River Company, Aiken, South Carolina (2002).

22. Edwards, T. B., D. K. Peeler and S. L. Marra, "Revisiting the Prediction Limits for Acceptable Durability," U.S. Department of Energy Report WSRC-TR-2003-00510, Revision 0, Westinghouse Savannah River Company, Aiken, South Carolina (2003). 
23. Jantzen, C. M., "The Impacts of Uranium and Thorium on the Defense Waste Processing Facility (DWPF) Viscosity Model," U.S. Department of Energy Report WSRC-TR-2004-00311, Revision 0, Westinghouse Savannah River Company, Aiken, South Carolina (2005).

24. Brown, K. G., C. M. Jantzen and G. Ritzhaupt, "Relating Liquidus Temperature to Composition for Defense Waste Processing Facility (DWPF) Process Control," U.S. Department of Energy Report WSRC-TR-2001-00520, Revision 0, Westinghouse Savannah River Company, Aiken, South Carolina (2001).

25. Brown, K. G., R. L. Postles and T. B. Edwards, "SME Acceptability Determination for DWPF Process Control," U.S. Department of Energy Report WSRC-TR-95-00364, Revision 4, Westinghouse Savannah River Company, Aiken, South Carolina (2002).

26. Li, H., P. Hrma, J. D. Vienna, M. Qian, Y. Su and D. E. Smith, "Effects of $\mathrm{Al}_{2} \mathrm{O}_{3}, \mathrm{~B}_{2} \mathrm{O}_{3}$, $\mathrm{Na}_{2} \mathrm{O}$, and $\mathrm{SiO}_{2}$ on Nepheline Formation in Borosilicate Glasses: Chemical and Physical Correlations," J. Non-Crystalline Solids, 331 202-216 (2003).

27. JMP ${ }^{\mathrm{TM}}$, Ver. 6.0.2, [Computer Software] SAS Institute Inc., Cary, NC (2005).

28. Taylor, A. S., T. B. Edwards, J. C. George, T. K. Snyder and D. K. Peeler, "The SRNL Composition - Properties (ComPro ${ }^{\mathrm{TM}}$ ) Database," U.S. Department of Energy Report WSRC-RP2004-00704, Revision 0, Westinghouse Savannah River Company, Aiken, South Carolina (2004).

29. Fox, K. M., D. K. Peeler and T. B. Edwards, "Request for QA Approval of Nepheline Database," U.S. Department of Energy Report SRNL-PSE-2006-00053, Washington Savannah River Company, Aiken, South Carolina (2006). 